BANCA D'ITALIA

E U R O S I S T E M A

Questioni di Economia e Finanza

(Occasional Papers)

Financial spillovers to emerging economies: the role of exchange rates and domestic fundamentals

by Alessio Ciarlone and Daniela Marconi

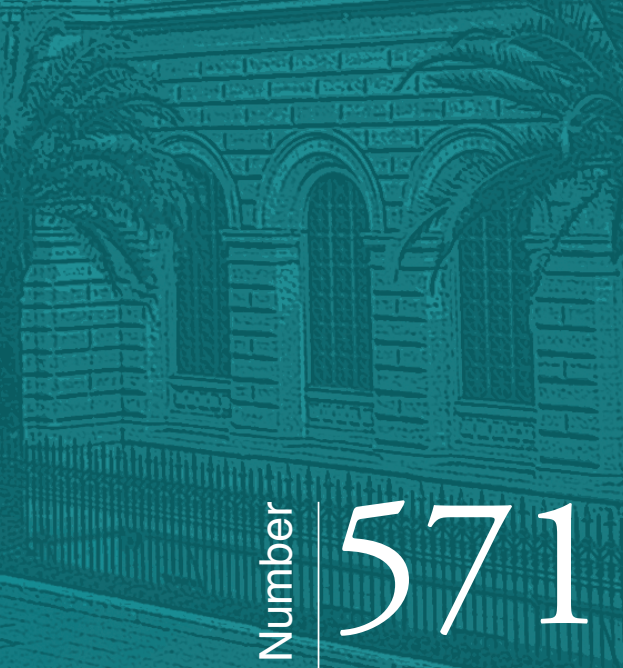





\section{Questioni di Economia e Finanza}

(Occasional Papers)

Financial spillovers to emerging economies:

the role of exchange rates and domestic fundamentals

by Alessio Ciarlone and Daniela Marconi

Number 571 - July 2020 
The series Occasional Papers presents studies and documents on issues pertaining to the institutional tasks of the Bank of Italy and the Eurosystem. The Occasional Papers appear alongside the Working Papers series which are specifically aimed at providing original contributions to economic research.

The Occasional Papers include studies conducted within the Bank of Italy, sometimes in cooperation with the Eurosystem or other institutions. The views expressed in the studies are those of the authors and do not involve the responsibility of the institutions to which they belong.

The series is available online at www.bancaditalia.it.

ISSN $1972-6627$ (print)

ISSN 1972-6643 (online)

Printed by the Printing and Publishing Division of the Bank of Italy 


\title{
FINANCIAL SPILLOVERS TO EMERGING ECONOMIES: THE ROLE OF EXCHANGE RATES AND DOMESTIC FUNDAMENTALS
}

\author{
by Alessio Ciarlone* and Daniela Marconi*
}

\begin{abstract}
Financial integration of emerging economies is on the rise and so are financial and monetary spillovers, especially those originating from US economic policy decisions and the (related) evolution of the US dollar. We revisit the "trilemma" vs. "dilemma" hypothesis and assess whether, and to what extent, exchange rate regimes and other relevant country fundamentals affect the sensitivity of domestic financial conditions to global risk aversion and US financial conditions. Results for a sample of 17 emerging economies over the period 19902018 suggest that the trilemma hypothesis appears to be still valid, as more flexible exchange rate regimes help in mitigating spillovers to stock market returns, sovereign spreads and real credit growth. However, other country fundamentals such as the current account, trade integration and US dollar debt exposure are also important factors.
\end{abstract}

JEL Classification: E42, E44, E52, F31, F36, F41, G15.

Keywords: trilemma, global financial cycle, financial conditions, emerging market economies, international policy transmission, spillovers.

DOI: $10.32057 / 0$.QEF.2020.571

\section{Contents}

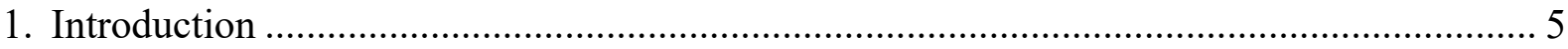

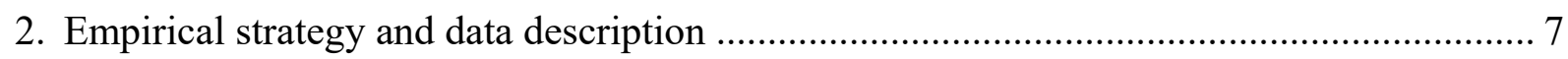

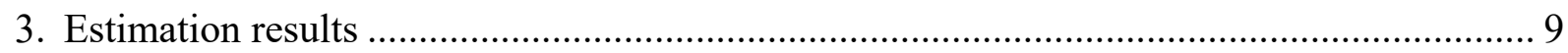

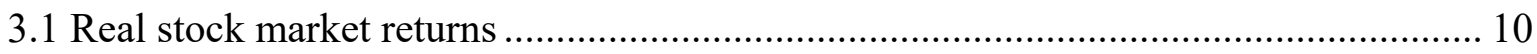

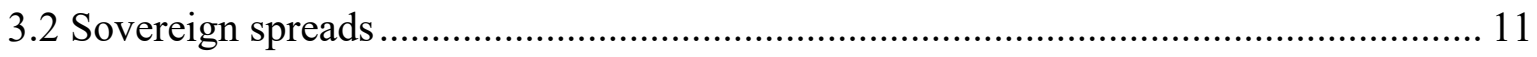

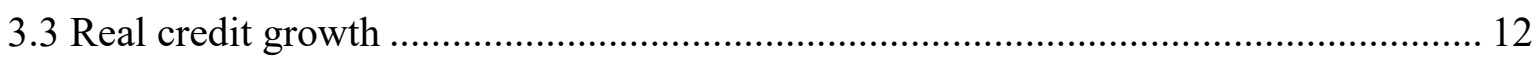

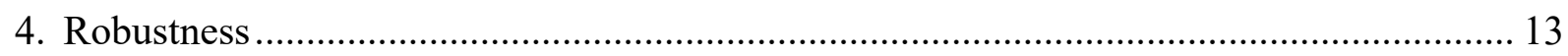

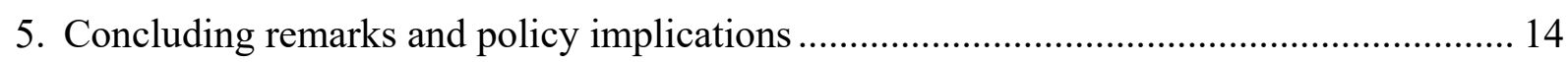

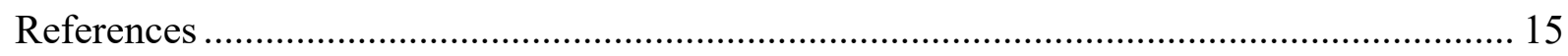

Appendix I. Charts and tables .................................................................................. 17

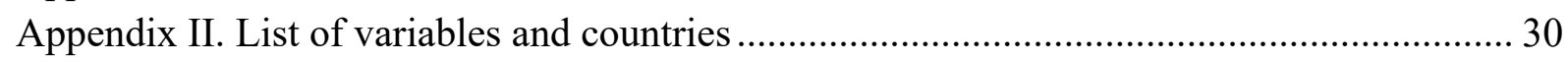

* Bank of Italy, Directorate General for Economics, Statistics and Research. Email: alessio.ciarlone@bancaditalia.it and daniela.marconi@bancaditalia.it. We wish to thank Giuseppe Parigi, Pietro Catte, Giovanni Veronese, Giorgio Merlonghi and Emidio Cocozza for their useful comments on earlier versions of this paper; any errors and omissions remain my own responsibility. The views expressed are those of the authors and do not necessarily reflect the views of the Bank of Italy. 



\section{Introduction}

Global financial integration has been increasing rapidly over the last twenty years, with crossborder asset and liability positions doubling as a ratio to global GDP. The pace of growth has been more rapid in advanced economies (AEs) - also reflecting the disproportionate rise in asset holdings absorbed by financial centres (Lane and Milesi Ferretti, 2017) - but it has been remarkable in emerging economies (EMEs) as well, where the average of gross external assets and liabilities has reached 60\% of GDP, up from less than 40\% in 1997 (Chart 1).

If, on the one hand, greater financial interconnectedness creates greater scope for risk sharing and improves an economy's ability to absorb idiosyncratic shocks, on the other hand it may also intensify the transmission of global shocks, especially those originating from US economic policy decisions and the (related) movements in the US dollar. Among financially interconnected economies, changes in the stance of monetary policy in core countries can quickly spill over to other countries. From this perspective, the 2008 global financial crisis and its aftermath - a period during which the Federal Reserve and many other central banks in AEs implemented new and unconventional forms of monetary stimulus - undoubtedly had important repercussion on EMEs financial conditions. Cross-border correlation across asset prices and credit growth has shown a relatively marked increase (Rey, 2013, 2015), reviving the debate over the risks posed by international spillovers not only to financial stability but also to monetary policy autonomy in EMEs. A key factor behind the stronger transmission of financial shocks from the US lies in the increasing debt exposure of EMEs non-bank borrowers in US dollar-denominated instruments (Chart 2).

Since the global financial crisis, an intense debate has emerged in policy and academic circles alike around to what extent individual countries can steer domestic financial conditions in a globally integrated financial system and which institutional features and fundamentals may endup increasing or decreasing these spillovers. The debate is still well alive today, as it was one of the key topic at the 2019 Jackson Hole Economic Symposium (Kameli-Özcan, 2019; Carney, 2019).

On the one hand, standard international macroeconomic theory - as exemplified by the Mundell-Fleming model - postulates that, in presence of free international capital movements, exchange rate flexibility allows domestic monetary policy to decouple from conditions abroad. By contrast, according to the famous "trilemma", a central bank cannot freely adjust its policy rate to stabilize domestic output while also maintaining a fixed exchange rate and an open capital account.

On the other hand, a set of seminal papers (Rey, 2013; Miranda-Agrippino and Rey, 2015; Rey, 2015 and 2016) have pointed out that increasing financial integration - especially if it occurs through instruments denominated in hard currency - has led to the emergence of a "global financial cycle". ${ }^{1}$ Given the dominant role of the US dollar in the international monetary system, they also argue that this "global financial cycle" appears to be strongly influenced by US monetary policy mainly through the leverage of global banks and the international role of the US dollar in credit markets (Bruno and Shin, 2015a and b). The emergence of such a common factor, able to shape financial conditions abroad, has two crucial implications. On the one hand, a stronger comovement of asset prices internationally would drastically limit the possibility for economic agents to diversify away idiosyncratic shocks through the acquisition of foreign assets. On the

\footnotetext{
1 In what follows, the terms "global financial cycle" and "global financial conditions" will be used interchangeably.
} 
other hand, it would also significantly reduce the ability of policy makers to steer domestic financial conditions away from global trends, for instance by adopting flexible exchange rates and running a monetary policy independent from that of the US. According to this view, the existence of a "global financial cycle" would morph the original trilemma into a "dilemma".

Yet, the empirical literature is not conclusive on the relative importance of global factors in shaping EMEs' financial conditions. Akinci (2013), for instance, finds that a global financial risk factor explains about $20 \%$ of the movements in spreads and aggregate activity in EMEs, concluding that the impact of shocks to the US risk-free interest rate on macroeconomic fluctuations in these countries is negligible overall. Klein and Shambaugh (2015), Obstfeld (2015) and Obsfeld et al. (2017) argue that a moderate amount of exchange rate flexibility does allow for at least some degree of monetary autonomy compared to pegs. ${ }^{2}$ Countries with fixed exchange rate regimes are more likely to build up financial vulnerabilities than those with relatively flexible regimes, thus magnifying the transmission of global financial shocks. Arregui et al. (2018) find that a common component (i.e. "global financial conditions") accounts for about 20 to $40 \%$ of the variation in EMEs domestic financial conditions, though with notable heterogeneity across countries. At the same time, they argue that a certain degree of exchange rate flexibility helps in absorbing external shocks, thereby allowing monetary policy to retain some control over domestic financial conditions. By focusing on capital inflows, Habib and Venditti (2019) find confirmation of a "trilemma", as countries that are more financially open and which adopt strict pegs are more sensitive to global risk shocks. ${ }^{3}$ In particular, for those EMEs characterised by an open capital account and exchange rate pegs, global risk shocks may impart a significant shift in capital flows compared to normal times. Finally, Lodge and Manu (2019) show that, although global factors appear to account for about half of the variation in risky asset prices across EMEs, the broader global environment plays a much stronger role in shaping domestic financial conditions in these countries than just US monetary shocks.

Another point to keep in mind is the following. The extant empirical literature on the "trilemma" vs. "dilemma" debate has focused its attention mainly upon the choice between a fixed vs. floating exchange rate regime as the main factor affecting EMEs sensitivity to sudden changes in global financial conditions and/or US monetary policy. By contrast, not enough attention has been devoted to other relevant real and financial country-specific characteristics that may play a role in this regard, such as the current account position, the degree of financial integration and financial exposure in hard currency. To begin with, years of ultra-low interest rates in AEs have led the private sector in many EMEs to increase its foreign currency-denominated liabilities. At the same time, more open capital accounts and higher degrees of integration into global financial markets have often resulted in higher current account deficits and increasing financial vulnerabilities (IMF, 2019). ${ }^{4}$

Against this backdrop, the aim of this paper is to revisit the trilemma-dilemma debate by considering more explicitly the country characteristics that, along with the peculiar exchange rate

\footnotetext{
${ }^{2}$ According to Han and Wei (2018) the behavioural dichotomy postulated by the trilemma is not clear cut in practice: when the centre country loosens its monetary policy, even countries with a flexible exchange rate regime tend to do the same to avoid an exchange rate appreciation.

${ }^{3}$ By investigating the structural drivers of this global risk measure, they find that financial shocks - which can be interpreted as exogenous changes in the risk bearing capacity of the financial sector - matter more than US monetary policy shocks in driving global risk.

${ }^{4}$ Of course, this list has no claim of being exhaustive, since there may be many other aspects at the individual country level which can be called into question.
} 
regime, can affect the sensitivity of domestic financial indicators to changes in international investors' degree of risk-aversion, US interest rates or US financial conditions. More precisely, we will focus on a few price and quantity indicators that best describe the state of domestic financial conditions in EMEs, namely stock market returns, sovereign credit spreads, money market rates and real credit growth.

For stock market returns and real credit growth our approach takes the approach reported in Obstfeld et al. (2017) as benchmark, while we are not aware of any paper in this framework that has looked at sovereign spreads and money market rates. Our analysis is more similar in spirit to Arregui et al. (2018), though an important difference lies in the choice of the dependent variables, which in their case are given by a synthetic index of domestic financial conditions encompassing several financial indicators. In our view, the advantage of having an overall indicator summarising the developments in many different segments of the financial system cannot counterbalance the disadvantage of not being able to identify the specific segment that is actually driving the overall index in a certain direction. Hence, our main contribution to the existing literature rests on the identification of the country characteristics that are more relevant in affecting the sensitivity to external financial and monetary shocks in specific segments of the financial system.

More in detail, in a panel comprising 17 of the largest EMEs, we look at whether the responsiveness of real stock market returns, sovereign spreads, money market rates and real credit growth to changes in global financial conditions differs depending not only on the exchange rate regime, but also on other country-specific fundamentals that may interact with global "riskon" and "risk-off" shocks, such as the degree of financial exposure to the US, the current account position, the degree of openness to international trade and so on.

The main results of our paper provide further support to the trilemma hypothesis and show that although global and US financial conditions spill over to EMEs, exchange rate flexibility and sound country-specific fundamentals may play a mitigating role in this regard. More interestingly, mitigating factors are market-specific: exchange rate flexibility plays a larger role for stock markets and short-term money market rates than sovereign spreads, while US-dollar debt exposure, current account positions and real and financial integrations matter more for sovereign spreads and credit conditions.

The paper is structured as follows. While Section 2 describes the adopted empirical strategy and the dataset, Section 3 delves into a detailed account of the estimation results for each of the market taken into account. After confirming the main results against a series of robustness checks in Section 4, Section 5 concludes by providing a set of policy implications.

\section{Empirical strategy and data description}

In this section, we describe the empirical strategy adopted to investigate the extent to which selected domestic financial variables are correlated with global financial indicators, using a panel comprising 17 of the largest EMEs from 1990 to 2018. In particular, we explore whether and to what extent various country-specific characteristics may interact with these global financial variables in amplifying $v s$. lessening the spillovers to domestic variables.

Based on other studies in the literature which have analysed the relationship among domestic and global financial variables (Bowman et al., 2015; Passari and Rey, 2015; Obstfeld et al., 2017; Arregui et al., 2018), our baseline specification can be summarised as follows: 


$$
f_{i t}=\alpha_{i}+\beta_{1} G F C_{t}+\beta_{2} \operatorname{CCHAR}_{i(t-k)}+\beta_{3} G F C_{t} * \operatorname{CCHAR}_{i(t-k)}+\beta_{4} Z_{i(t-k)}+\beta_{5} G V_{t}+\varepsilon_{i t}
$$

where $f_{i t}$ is a financial variable in country $i$ in period $t$; $G F C_{t}$ is a measure of "global financial conditions"; $C_{C H A R_{i(t-k)}}$ is the vector of relevant country characteristics, which are then interacted with the different proxies of the "global financial cycle"; $Z_{i(t-k)}$ comprises other domestic controls considered to be relevant in affecting the dynamics of the given financial variable; and $G V_{t}$ includes other global variables. Finally, $\alpha_{i}$ captures country fixed effects and $\varepsilon_{i t}$ is the random error term.

Four different types of domestic financial variables are taken into account: real stock market returns (in local currency); the differential between the yields on US dollar-denominated sovereign bonds and their US counterpart (sovereign spreads); real short-term money market rates and the growth rate of the stock of real credit to the private non-financial sector. ${ }^{5}$ In our view, they represent the essential set of variables widely analysed by international financial institutions and market analysts to assess EMEs' financial conditions.

In order to capture the evolution of a "global financial cycle" $\left(G F C_{t}\right)$, we take into account different proxies. The first one is the Chicago Board Options S\&P 100 Volatility Index (VXO); this index (or its analogous, the VIX, computed on the S\&P 500 index) is usually considered an indicator of the tightness of financial conditions around the world and a measure of global risk aversion. Indeed, a large body of literature has shown that global capital flows, global credit growth and global asset prices co-move quite tightly with it (Ahmed and Zlate, 2014; Bruno and Shin, 2015b; Rey, 2015; Miranda-Agrippino and Rey, 2015, Obstfeld et al., 2017; Adrian et al. 2019; Buono et al. 2019, among others). Following the approach proposed by Obstfeld et al. (2017), we also consider the real shadow federal funds rate, the real T-bill rate and the term spread. Moreover, in the vein of Arregui et al. (2018), we also take into account an index of US financial conditions (adjusted for cyclical conditions) published by the Chicago Fed to account for additional spillovers from US monetary and financial conditions. ${ }^{6}$ Finally, we consider the US dollar nominal effective exchange as well, the role of which in shaping global liquidity has been recently emphasized by Avdjev et al. (2019). ${ }^{7}$

The set of country characteristics $C C H A R_{i(t-k)}$ includes, first of all, the exchange rate regime chosen by the individual emerging economy. Our classification is based on the one provided by Ilzetzki et al. (2016) at monthly frequencies, which is reported in Table 1.a. ${ }^{8}$ We have grouped the original finer classification codes into three broader categories: i) fixed exchange rate regimes (light blue); ii) intermediate exchange rate regimes (light pink); and iii) floating exchange rate regimes (light green). We drop all the observations related to the last two categories (14 and 15)

\footnotetext{
${ }^{5}$ In the estimations, we use the three-quarter moving average of the yearly growth rate of real credit to the private sector to reduce noise.

${ }^{6}$ As in Obstfeld et al. (2017), real interest rates are calculated by subtracting 1-period forward inflation to nominal interest rates. The term spread is calculated by the difference between the yields of a 10-year treasury constant maturity bond and a 3-month treasury constant maturity; a negative term spread (i.e. and inversion of the yield curve), is often found to be a good predictor of economic downturn in the US.

${ }^{7}$ In what follow, the trade-weighted movement of the US dollar against a basket of six major currencies (Canadian dollar, euro, yen, British pound, Swiss franc and Swedish krona) will be used.

${ }^{8}$ For each currency, the authors compute the co-movements with all other currencies to detect anchor currencies and then apply a statistical method to assess the degree of flexibility against the anchor currency. Freely floating currencies have no anchor.
} 
of the original classification since they are generally associated with currency crises. At the end of this procedure, about $25 \%$ of the observations in our sample fall in the intermediate regime, while the rest is equally distributed between the fixed and the floating regimes. The classification by Ilzetzki et al. (2016) is continuous in time-series terms: therefore, all the countries in our sample have changed exchange rate regime several times across the sample period, the only exceptions being Mexico and South Africa which have always had free-floating regimes (see Table 1.b). ${ }^{9}$ This time-series variation in exchange rate regimes is a valuable characteristic, as it reduces the possibility that this classification ends up capturing other time-invariant cross-country differences. In all the estimations, the benchmark regime is the intermediate one.

Beyond this feature, we have enriched the set of country characteristics that can play a role in affecting EMEs sensitivity to changes in the "global financial cycle". We take into account classic measures of external imbalances - i.e. the current account balance-to-GDP ratio - as well as of both financial integration and capital account openness - traditionally described, respectively, by the Lane and Milesi-Ferretti ratio of foreign assets and liabilities to GDP and by the Chinn-Ito index. The degree of "financial" dependence on the US is proxied by the outstanding stock of US dollar-denominated loans and debt securities of the non-financial private sector, taken as a ratio to GDP or to the stock of foreign reserves. We also considered the degree of "real" dependence on the US - calculated as the ratio of exports and imports to and from the US to domestic GPD - as well as a more general measure of openness to international trade.

Our parameters of interest are those associated with the interaction terms between global variables and country characteristics (i.e. the $\beta_{3} \mathrm{~s}$ ), which are intended to capture the existence of non-linearities in the transmission of global financial conditions.

The other domestic controls are grouped in the matrix $Z_{i(t-k)}$ : the domestic real GDP growth rate; the real credit growth rate or the credit-to-GDP ratio; the public debt-to- GDP ratio; the domestic policy rate; the nominal effective exchange rate; the ratio between liability inflows and GDP; a dummy for the occurrence of a banking crisis. All domestic controls are adequately lagged in order to mitigate endogeneity concerns. Country characteristics and domestic controls are introduced differently in the different specifications.

Finally, the class of additional global controls $G V_{t}$ includes oil price inflation, the real GDP growth rate of OECD countries and a dummy variable for the global financial crisis.

Time series of the previous variables have been gathered together from several sources, including Refinitiv, the BIS, the IMF, national sources as well as the freely available datasets of the Lane and Milesi-Ferretti (2017) financial integration measure, the Chinn and Ito (2006) index of capital account openness and the Laeven and Valencia (2018) dating of financial crises. Details of these series and their construction, as well as the list of the 17 largest EMEs belonging to our sample, are provided in Appendix II.

\section{Estimation results}

The models for real stock returns, sovereign spreads and money market rates are estimated on monthly frequencies over the period 1995M1-2018M11, and explanatory variables are lagged

\footnotetext{
${ }^{9}$ It must be stressed that here fixed exchange rate regimes do not correspond to strict pegs, but rather to a whole range of exchange rate regimes with limited flexibility, spanning from currency union to de facto crawling band that is narrower than or equal to $+/-2 \%$. Moreover, the allocation of countries across the three regimes is time varying.
} 
one period. The regressions for the growth rate of real domestic credit to the non-financial private sector use data at the quarterly frequency over the period 1995Q1-2018Q3; all explanatory variables are lagged two periods, so that the respective coefficients may be interpreted as the impact of the variables prevailing at the beginning of a quarter upon the average real credit growth observed throughout the quarter. All the models are estimated with a fixed-effect DriscollKraay estimator to account for possible omitted variables and any remaining cross-sectional and temporal dependence in the error term.

\subsection{Real stock market returns}

Table 2 reports the results for real stock market returns, replicating the main features of the specification put forward by Obstfeld et al. (2017). In what follows, stock returns in local currency are taken into account; however, results hold also for US dollar denominated stocks (measured by MSCI indexes) and are available from the authors upon request. Estimates confirm that real stock market returns are significantly negatively affected by the global risk aversion (column(1)), and this effect is apparently independent from the adopted exchange rate regime (column(2)). In particular, a one standard deviation increase in the VXO index implies an approximate 1.5\% decline in stock exchange returns. Turning to the impact of US real interest rates (column (3) for the real T-bill rate and column (5) for the real shadow federal funds rate), we surprisingly find a positive impact though we suspect that the result may be distorted by expected developments in US inflation rate. In fact, if we consider nominal reference rates while controlling for US inflation rate (column(4) and (6), respectively), the coefficient of both variables is negative and much larger for the inflation rate, therefore suggesting that stock market returns may be more sensitive to expected policy rate changes than to the actual real interest rates included in the equation. Finally, in this basic specification real stock market returns do not appear to be sensitive to changes in overall US financial conditions (column (7)).

In Table 3, we focus on the shadow federal funds rate and the overall US financial condition index using a different and richer specification. First of all, we introduce the log change of the VXO along with the log of the VXO index, as suggested in Rey (2015). Also, given the high persistence of real interest rates and US financial condition index, we consider the first difference of these variables rather than their level. We also control for relevant country characteristics - such as the current account position and the degree of financial and trade integration - as well as for other relevant global factors - such as the trade-weighted movement of the US dollar against a basket of six major currencies. Controlling for the log change of the VXO, we find that the sensitivity of stock market returns to global risk aversion does differ across exchange rate regimes, the negative impact being stronger in countries characterised by fixed exchange rate regimes (column (1)). Moreover, stock exchange returns are negatively associated with the size of the increase in real federal funds rates in countries with fixed exchange rate regimes (column (2)), suggesting that the size of the change in the US monetary conditions matters more than the level. Results in column (3) indicate that the sensitivity to US real rate changes does not depend on the degree of "financial" dependence on the US dollar, while results in column (4) suggest that the negative impact of more restrictive financial conditions in the US is lower for countries with stronger "real" dependence on the US. As a matter of fact, in our sample trade integration with the US is stronger for countries with more flexible exchange rates. Results are somewhat similar if we consider the change in the overall US financial condition index (columns (5)-(8)). Finally, in columns (9) and (10) we check whether the sensitivity of real stock market returns to the VXO is affected by the 
current account position of the country or its financial exposure to the US dollar. Results indicate that the former does matter in mitigating global financial spillovers to real stock market returns, while the latter does not. ${ }^{10}$ Among the other variables of interest, we find a negative impact from an appreciation of the US dollar against other major currencies, a positive impact of the level of current account to GDP and a positive impact of financial integration. World trade integration and foreign exchange reserves to GDP, instead, are on average associated with lower real stock market returns.

Summing up, we find evidence that the exchange rate regime does matter in the determining the sensitivity of stock market returns to the VXO as well as to changes in US financial conditions, pointing to the validity of the trilemma hypothesis as far as the transmission of financial and monetary shocks to this market. Moreover, VXO spillovers are larger in countries with weaker current account positions, indicating that other country fundamentals matter as well in shaping resiliency to external shocks.

\subsection{Sovereign spreads}

Looking at sovereign spreads on dollar-denominated bonds, the results reported in Table 4 show that their sensitivity to the VXO are large and statistically significant.11,12 Compared to intermediate exchange rate regimes, the sensitivity is larger for fixed regimes and even more for floating ones (column (2)). However, this result must be interpreted with caution, as the abrupt shift of the sign associated with the dummy variables for fixed and floating regimes going from column (1) to column (2) indicates that the coefficient may be unstable. ${ }^{13}$ The real US federal funds rate has a strong and positive impact on sovereign spreads: a one standard deviation increase the real US federal funds rate (about 113 basis points) implies an increase in sovereign spreads of about 16 basis points on average (column (5)). Moreover, the increase is larger in case of fixed and intermediate regimes (29 basis points) and smaller for floating regimes (11 basis points). The overall US financial condition index does not seem to have much of an impact (columns (4) and (6)).

For comparison, in column (7) we consider as dependent variable the real short-term rate (money market and interbank rates). Results show that short-term rates are positively affected by the VXO in fixed exchange rate regimes, while they are negatively affected in intermediate regimes and less so in floating regimes. In turn, the real US federal funds rate has a positive impact on short-term rates in case of intermediate and fixed regimes and a negative impact in case of

\footnotetext{
10 The coefficients in columns (9) and (10) imply that the negative impact of one standard deviation increase in $\log$ (VXO) would be compensated by a current account balance of at least 5\% of GDP.

${ }^{11}$ Focusing on dollar-denominated sovereign spread allow us to abstract from the response of yields to exchange rate movements, focusing on risk premia (Gilchrist et al., 2019; Kameli-Özcan, 2019).

12 Regression in column (1) implies that one standard deviation increase in log(VXO) is associated with 44 basis points increase in sovereign spreads. We do not include the log change of VXO because it is not statistically significant, with results available from the authors upon request.

${ }^{13}$ In column (1) the coefficient associated with the dummy variable for exchange rates are evaluated at the average level of $\log (\mathrm{VXO})$, which is about 2.9. From column (2) onwards, the coefficients of the dummies are evaluated at $\log (\mathrm{VXO})=0$, a value that never occurs. Nonetheless, the indication is that when the VXO takes on very low values countries with floating regimes have considerably lower sovereign spreads. If the VXO were equal to 1 (as opposed to an average value of 8.8), countries with floating regimes would have a sovereign spread of almost 400 basis points lower.
} 
floating regimes, suggesting that the exchange rate does play a role in absorbing monetary policy spillovers and hence giving again support to the trilemma hypothesis.

A unit root test reveals that sovereign spreads are non-stationary (as shocks to them tend to be very persistent); hence, we run regressions in first differences. In Table 5, we report results only for the US financial conditions index because the federal funds rate is never statistically significant in first-difference regressions. ${ }^{14}$ In column (1) to (5), we report the results for the change in the adjusted US financial condition index. In order to control for the possible collinearity between this indicator and the VXO, in columns (6) to (10) we also consider the change in the portion of the US financial condition index that is orthogonal to the VXO. In all cases, results confirm that the sensitivity to US financial conditions is stronger in less flexible exchange rate regimes. As regards the impact of the VXO, even though it does not depend on the exchange rate regime (unreported result), we find that a better current account position and greater trade integration with the US or the rest of the world are all important fundamentals in mitigating the spillovers to sovereign spreads, while greater dollar-debt exposure magnifies them.

To sum up, sovereign bond yields are always negatively affected by global risk aversion, while spillovers from US financial conditions are stronger for countries with less flexible exchange rate regimes, higher US dollar-debt exposure, weaker current account positions and lower trade integration.

\subsection{Real credit growth}

The estimation results for real credit growth are presented in Tables 6 to 10, which differ in that they focus each on a specific country characteristic.

Controlling for relevant domestic and common factors, real credit growth in our sample of EMEs is strongly negatively related to the VXO index across all the reported model specifications. Once interaction terms are taken into account, EMEs characterised by a higher share of US dollar denominated private sector debt appear to be more vulnerable to sudden adverse shifts in international investors' degree of risk aversion. In fact, as shown in Table 7, the coefficient on the interacted term with the measure of hard-currency debt exposure is negative and statistically significant, with a one standard deviation increase in the log(VXO) implying about 0.6 percentage point lower real credit growth in countries more highly indebted in US dollars. Estimation results reported in Table 10, by contrast, would suggest that a higher degree of trade integration is able to mitigate the adverse consequences of sudden adverse movements in the VXO index. No other country characteristic - neither the exchange rate regime, nor the degree of financial integration or the balance on the current account - appears to exert any reinforcing (i.e. weakening) impact on EMEs' sensitivities to changes in this measure of the "global financial cycle", giving some support to the dilemma hypothesis.

Estimation results would also suggest another relatively robust conclusion: in our sample of EMEs, real credit growth appears to be negatively related also to the effective exchange rate of the US dollar against the currencies of the six US main trading partners. We interpret this result as a further evidence of the "financial" channel of transmission put forward by Avdjiev et al. (2019), according to which a stronger dollar in international markets is accompanied by lower capital inflows towards EMEs - mainly in the "other investment" category - and, as a consequence, by

\footnotetext{
${ }^{14}$ Results are available from the author upon request.
} 
tighter domestic financial conditions in recipient economies in the form of lower credit growth. According to the results shown in Table 6 and Table 9, EMEs characterised by fixed exchange rate regimes or by a higher degree of capital account openness/financial integration are more sensitive to the effects of shocks to this proxy for the global financial cycle. Mimicking previous results, greater openness to international trade would instead mitigate the effects of adverse US dollar movements.

The Chicago Fed index of US financial conditions does not appear to exert any significant effect upon the dynamics of real credit in our sample of EMEs. Moreover, only in few model specifications does the real shadow fed funds rate or the term spread turn out to influence in a significant manner the chosen dependent variable. This conclusion seems to be in line with other results (Habib and Venditti, 2019; Lodge and Manu, 2019) according to which - although US monetary shocks have some influence in shaping EMEs financial conditions - the broader global and domestic environment plays a significantly stronger role. For instance, real credit growth appears to be overall more resilient in countries with fixed or floating regimes compared to countries with intermediate regimes, especially when controlling for the domestic policy response. In fact, as shown in Table 7, the interaction terms with both the real US shadow rate and the term spread are positive and statistically significant. At the same time, nevertheless, countries characterised by a larger stock of US dollar-denominated debt, worse current account positions and a higher degree of openness to international trade appear to be more vulnerable against shocks to US monetary policy, as suggested by the results contained in Table 8, Table 9 and Table 10, respectively.

As a concluding remark, although global financial conditions loom large, the reported empirical evidence suggests that countries still appear to hold considerable sway over domestic credit conditions through monetary policy (Obstfeld et al., 2017; Arregui et al., 2018). Throughout all the possible model specifications, in fact, the coefficients associated to the domestic reference rates always display the expected negative sign and turn out to be highly statistically significant. ${ }^{15}$.

To sum up, according to the reported estimation results, in our sample of EMEs real credit growth appears to be negatively related to two proxies of the "global financial cycle", i.e. the VXO index and the US dollar effective exchange rate. Countries with fixed exchange rate regimes, more "financially" dependent on the US dollar and more integrated into global financial markets appear to be more exposed to shocks to the previous indicators; on the contrary, greater openness to international trade seems to provide some shield against such adverse variations. Overall, US monetary policy indicators does not seem to exert a significant impact on domestic credit growth in our sample of EMEs, except in countries characterised by a large stock of US dollar denominated private sector debt or by ample current account deficits. Contrary to mainstream results - though not completely at odds with anecdotal evidence and policy discussions - fixed exchange rate regimes appear to provide a sort of shield against sudden adverse movements in US monetary conditions.

\section{Robustness}

We performed robustness exercises to make sure that our results are stable over time. In particular, we split the sample period into before and after the global financial crisis and check

15 The effect is even stronger in case of more flexible exchange rate regimes. Results are available from the author upon request. 
whether the sensitivity of stock market returns and sovereign spreads to external monetary and financial conditions have changed after the global financial crisis. Results are reported in Tables 11-12. For brevity, we report only the sign of the estimated parameters and their statistical significance in the two sample periods. Regressions for stock market returns show that, over time, exchange rate regimes have lost some of their role in transmitting external financial conditions to stock markets, while country fundamentals, such as current account position, dollar debt exposure and trade integration with the US, have become more important. As for sovereign spreads, results indicate that parameters are quite stable over time, exchange rate regimes and other country fundamental retain their significant role in shaping the sensitivity to external financial conditions.

\section{Concluding remarks and policy implications}

In this paper, we revisit the "trilemma"-"dilemma" debate and analyse whether and to what extent exchange rate regimes and other country-specific fundamentals interact with global financial variables in shaping the sensitivity to the global financial cycle of real stock market returns, sovereign spreads and real credit growth in a sample of 17 of the largest EMEs. Results indicate that domestic financial markets suffer the impact of adverse shocks to external financial conditions, more so in countries characterised by fixed exchange rate regimes, worse capital account positions and higher levels of dollar-denominated private sector debt and lower real integration. Overall, our results provide some support to the trilemma hypothesis and show that, although global and US financial conditions spill over to emerging economies, exchange rate flexibility and sound country-specific fundamentals may play a mitigating role. More interestingly, the mitigating factors are market-specific: exchange rate flexibility plays a larger role in mitigating spillovers to stock markets and, to a lesser extent, to sovereign spreads, while US-dollar debt exposure, current account positions and real and financial integrations matter more for sovereign spreads and credit conditions. 


\section{References}

Adrian, T., Stackman, D., Vogt, E., 2019 “Global Price of Risk and Stabilization Policies”, IMF Econ Rev (2019) 67: 215. https://doi.org/10.1057/s41308-019-00075-3

Ahmed, S., Zlate, A., 2014, "Capital Flows to Emerging Market Economies: A Brave New World?" Journal of International Money and Finance, Vol. 48, pp. 221-248.

Akinci, 0., 2013, "Global Financial Conditions, Country Spreads and Macroeconomic Fluctuations in Emerging countries", Technical report.

Arregui, N., Elekdag, S., Gelos, R.G., Lafarguette, R., Seneviratne, D., 2018, “Can Countries Manage Their Financial Conditions Amid Globalization?” IMF Working Papers 18/15.

Avdjiev, S., Bruno, V., Koch., C., Shin, H.S., 2019, “The Dollar Exchange Rate as a Global Risk Factor: Evidence from Investment", IMF Economic Review, Vol. 67, pp. 151-173.

Bowman, D., Londono, J.M., Sapriza, H., 2015, "US Unconventional Monetary Policy and Transmission to Emerging Market Economies", Journal of International Money and Finance, Vol. 55, pp. 27-59.

Bruno, V., Shin, H.S., 2015a, "Capital Flows and the Risk-Taking Channel of Monetary Policy", Journal of Monetary Economics, Vol. 71, pp. 119-132.

Bruno, V., Shin, H.S., 2015b, "Cross-border Banking and Global Liquidity", The Review of Economic Studies, Vo. 82, pp. 535-564.

Buono, I., Corneli, F., Di Stefano, E., 2019, "Capital inflows to emerging countries and their sensitivity to the global financial cycle”, Bank of Italy, mimeo.

Carney, M., 2019, "The Growing Challenges for Monetary Policy in the current International Monetary and Financial System", Speech given at the Jackson Hole Symposium 2019, 23 August 2019.

Carstens, A., 2019, "Exchange rates and monetary policy frameworks in emerging market economies", Lecture at the London School of Economics, available here.

Chinn, M.D., Ito, H., 2006, "What Matters for Financial Development? Capital Controls, Institutions, and Interactions", Journal of Development Economics, Vol. 81(1), pp. 163-192.

Fratzscher, M., Lo Duca, M., Straub, R., 2018, "On the International Spillovers of US Quantitative Easing”, The Economic Journal, Vol. 128(608), pp. 330-377.

Gilchrist, S., Yue, V., Zakrajšek, E., "US Monetary Policy and International Bond Markets", NBER Working Paper No. 26012.

Habib, M.M., Venditti, F., 2019, "The Global Capital Flows Cycle: Structural Drivers and Transmission Channels", ECB Working Paper No. 2280.

Han, X., Wei, S.J., 2018, "International Transmissions of Monetary Shocks: Between a Trilemma and a Dilemma", Journal of International Economics, Vol. 110, pp. 205-219.

Ilzetzki, E., Reinhart, C.M., Rogoff, K.S., 2017, "Exchange Arrangements Entering the 21st Century: Which Anchor Will Hold?", NBER Working Paper No. 23134.

International Monetary Fund, 2017, Global Financial Stability Report, April.

International Monetary Fund, 2019, World Economic Outlook, April. 
Kalemli-Özcan, S., 2019, "U.S. Monetary Policy and International Risk Spillovers", Proceedings, Jackson Hole.

Klein, M.W., Shambaugh, J.C., 2015, "Rounding the Corners of the Policy Trilemma: Sources of Monetary Policy Autonomy”, American Economic Journal: Macroeconomics, Vol. 7(4), pp. 33-66.

Laeven, L., Valencia, F., 2018, "Systemic Banking Crises Revisited”, IMF Working Paper No. $18 / 206$.

Lane, P.R., Milesi-Ferretti, G.M., 2017, "International Financial Integration in the Aftermath of the Global Financial Crisis", IMF Working Paper No. 17/115.

Lodge, D., Manu, A.S., 2019, "EME Financial Conditions: Which Global Shocks Matter?, ECB Working Paper No. 2282.

Miranda-Agrippino, S, Rey, H., 2015, "US Monetary Policy and the Global Financial Cycle", NBER Working Paper No. 21722.

Obstfeld, M., 2015, "Trilemmas and Trade-Offs: Living with Financial Globalization", BIS Working Paper 480.

Obstfeld, M, Ostry, J.D., Qureshi, M.S., 2017, "A Tie That Binds: Revisiting the Trilemma in Emerging Market Economies,” IMF Working Paper 17/130

Obstfeld, M., Taylor, A.M., 2017, "International Monetary Relations: Taking Finance Seriously", NBER Working Paper No. 23440.

Passari, E., Rey, H., 2015, “Financial Flows and the International Monetary System," Economic Journal, Vol. 125(584), pp. 675-698.

Rey, H., 2013, "Dilemma not Trilemma: The Global Financial Cycle and Monetary Policy Independence”. Proceedings, Jackson Hole.

Rey, H., 2015, "Dilemma not Trilemma: The Global Financial Cycle and Monetary Policy Independence”, NBER Working Paper No. 21162.

Rey, H., 2016, "International Channels of Transmission of Monetary Policy and the Mundellian Trilemma," IMF Economic Review, Vol. 64(1), pp. 6-35. 
Chart 1. International financial integration: gross external assets and liabilities (in \% of GDP)

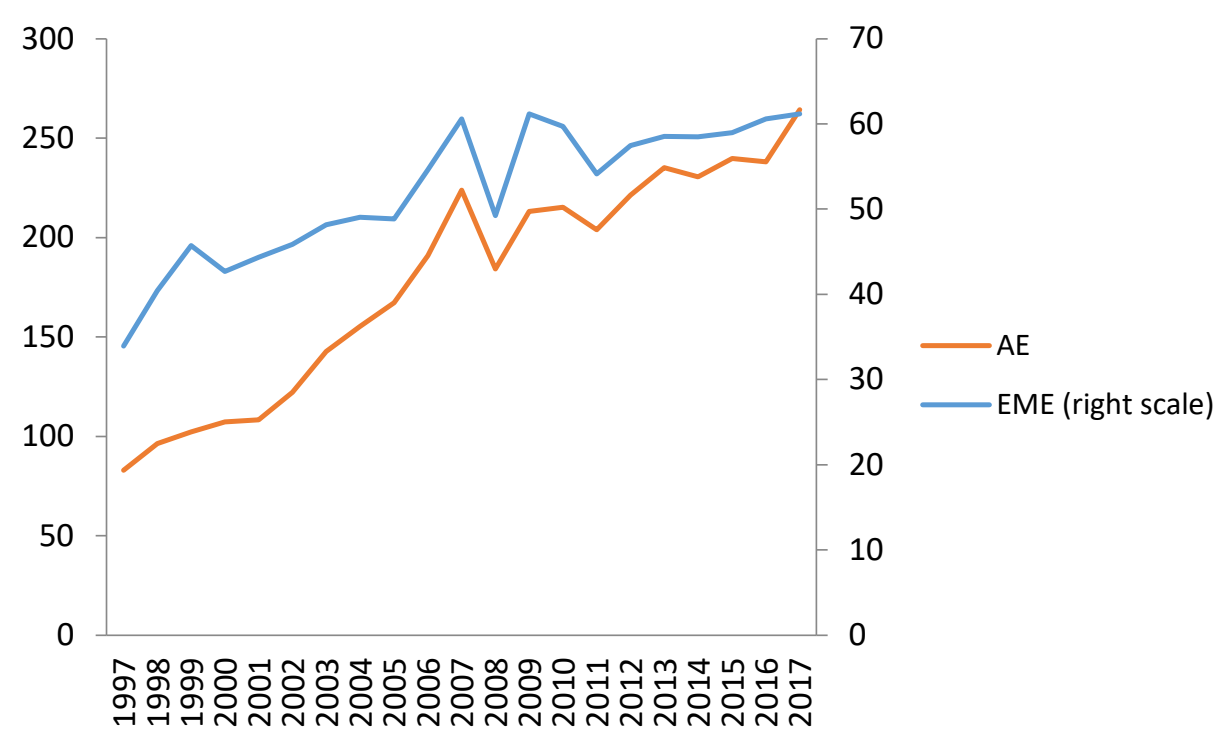

Source: Lane and Milesi-Ferretti (2017) and IMF.

Fig.2: Foreign currency credit to EMEs' non-bank sector by currency denomination
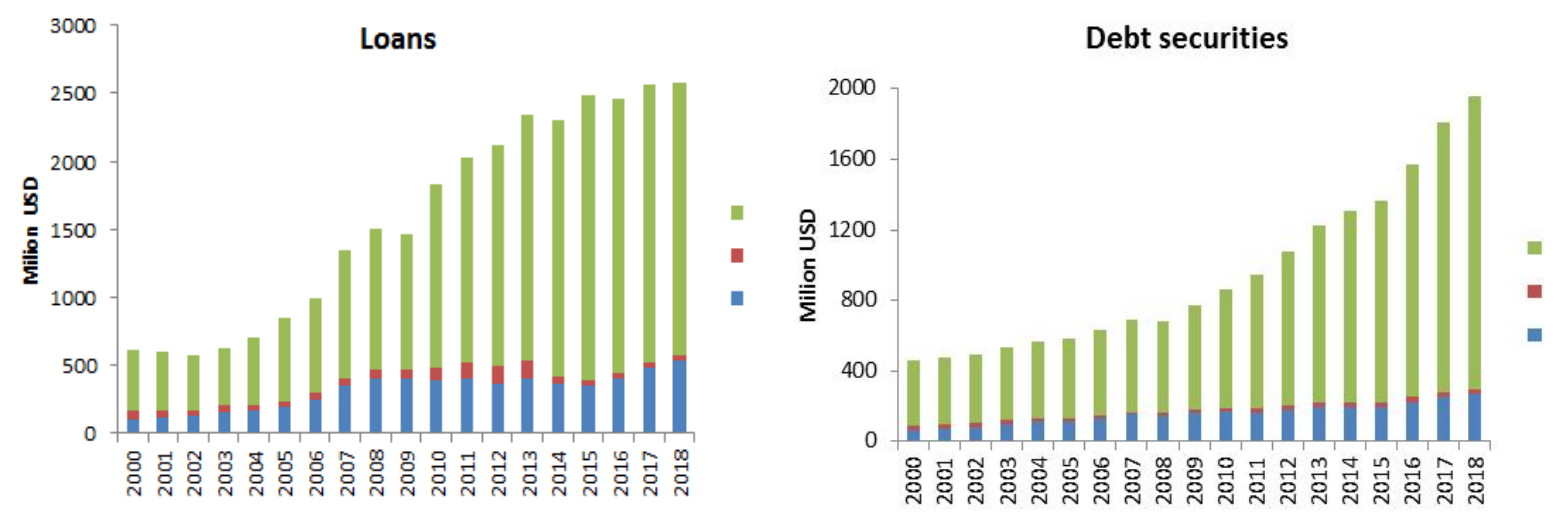

Source: BIS, global liquidity indicators. 
Table 1.a Exchange rate arrangement classification

\begin{tabular}{|c|c|c|}
\hline $1 \cdot$ & No separate legal tender or currency union & \multirow{8}{*}{ Fixed } \\
\hline $2 \bullet$ & Pre announced peg or currency board arrangement & \\
\hline $3 \bullet$ & Pre announced horizontal band that is narrower than or equal to $+/-2 \%$ & \\
\hline $4 \cdot$ & De facto peg & \\
\hline $5 \bullet$ & $\begin{array}{l}\text { Pre announced crawling peg; de facto moving band narrower than or equal to } \\
+/-1 \%\end{array}$ & \\
\hline $6 \bullet$ & $\begin{array}{l}\text { Pre announced crawling band that is narrower than or equal to }+/-2 \% \\
\text { or de facto horizontal band that is narrower than or equal to }+/-2 \%\end{array}$ & \\
\hline $7 \bullet$ & De facto crawling peg & \\
\hline $8 \cdot$ & De facto crawling band that is narrower than or equal to $+/-2 \%$ & \\
\hline $9 \bullet$ & Pre announced crawling band that is wider than or equal to $+/-2 \%$ & \multirow{3}{*}{ Intermediate } \\
\hline $10 \bullet$ & De facto crawling band that is narrower than or equal to $+/-5 \%$ & \\
\hline $11 \cdot$ & $\begin{array}{l}\text { Moving band that is narrower than or equal to }+/-2 \% \text { (i.e., allows for both appreciation and } \\
\text { depreciation over time) }\end{array}$ & \\
\hline $12 \bullet$ & De facto moving band $+/-5 \% /$ Managed floating & \multirow{2}{*}{ Flexible } \\
\hline $13 \bullet$ & Freely floating & \\
\hline $14 \cdot$ & Freely falling & \multirow{2}{*}{ Not included } \\
\hline $15 \bullet$ & Dual market in which parallel market data is missing. & \\
\hline
\end{tabular}

Source: Ilzetzki, Reinhart and Rogoff (2016)

Table 1.b Exchange rate regimes distribution over time across sample countries

\begin{tabular}{llll}
\hline & Fixed & Intermediate & Floating \\
\hline Brazil & $1995-98$ & No & $1999-2018$ \\
Chile & No & $1995-98$ & $1999-2018$ \\
China & $1995-2018$ & No & No \\
Colombia & No & $1995-99$ & $2000-2018$ \\
Czech Republic & $1995 / 1998-2018$ & $96-97$ & No \\
Hungary & $1995-1998 / 2009-2018$ & $1999-2008$ & No \\
India & $1995-2009 / 2013-2018$ & $2009-2012$ & No \\
Indonesia & $1995-97 / 2007-2013$ & $2014-2018$ & $1999-2007$ \\
South Korea & $1995-97$ & $1998-2014$ & $2015-2018$ \\
Malaysia & $1995-97 / 1999-2005$ & $2005-2015$ & $1997-98 / 2016-2018$ \\
Mexico & No & No & $1995-2018$ \\
Philippines & $1996-97 / 2000-2004$ & $1995 / 2005-2018$ & $1998-99$ \\
Poland & $2012-2018$ & $1995-98$ & $1999-2011$ \\
Russia & $1995-2008$ & $2009-2018$ & No \\
South Africa & No & No & $1995-2018$ \\
Thailand & $1995-97$ & $2000-2018$ & $1998-99$ \\
Turkey & No & $1995-2000$ & $2001-2018$ \\
\hline
\end{tabular}

Source: Based on Ilzetzki, Reinhart and Rogoff (2016) 
Table 2. Real stock returns in EMEs - basic regressions - 1995M1-2018M11

\begin{tabular}{|c|c|c|c|c|c|c|c|}
\hline & $\begin{array}{r}\text { (1) } \\
\text { VXO }\end{array}$ & $\begin{array}{r}(2) \\
\text { VXO*EXREG }\end{array}$ & $\begin{array}{r}\text { (3) } \\
\text { RUSTBILL }\end{array}$ & $\begin{array}{r}\text { (4) } \\
\text { USTBILL }\end{array}$ & $\begin{array}{r}\text { (5) } \\
\text { RUSFFR }\end{array}$ & $\begin{array}{r}6) \\
\text { USFFR }\end{array}$ & $\begin{array}{r}(7) \\
\text { USANFCI }\end{array}$ \\
\hline Fixed regime & $\begin{array}{r}0.001 \\
(0.006)\end{array}$ & $\begin{array}{r}0.025 \\
(0.025)\end{array}$ & $\begin{array}{r}0.020 \\
(0.026)\end{array}$ & $\begin{array}{r}0.013 \\
(0.026)\end{array}$ & $\begin{array}{r}0.008 \\
(0.029)\end{array}$ & $\begin{array}{r}0.016 \\
(0.024)\end{array}$ & $\begin{array}{r}0.011 \\
(0.031)\end{array}$ \\
\hline Floating regime & $\begin{array}{l}0.017^{* *} \\
(0.008)\end{array}$ & $\begin{array}{r}0.005 \\
(0.021)\end{array}$ & $\begin{array}{r}0.006 \\
(0.020)\end{array}$ & $\begin{array}{r}-0.007 \\
(0.018)\end{array}$ & $\begin{array}{r}-0.019 \\
(0.019)\end{array}$ & $\begin{array}{r}0.010 \\
(0.019)\end{array}$ & $\begin{array}{r}0.009 \\
(0.026)\end{array}$ \\
\hline $\log (\mathrm{VXO})$ & $\begin{array}{r}-0.042^{* * *} \\
(0.010)\end{array}$ & $\begin{array}{r}-0.041^{* * *} \\
(0.011)\end{array}$ & $\begin{array}{r}-0.041^{* * *} \\
(0.010)\end{array}$ & $\begin{array}{r}-0.050^{* * *} \\
(0.010)\end{array}$ & $\begin{array}{r}-0.048^{* * *} \\
(0.009)\end{array}$ & $\begin{array}{r}-0.047^{* * *} \\
(0.010)\end{array}$ & $\begin{array}{r}-0.054^{* * *} \\
(0.011)\end{array}$ \\
\hline Fixed*log(VXO) & & $\begin{array}{r}-0.009 \\
(0.009)\end{array}$ & $\begin{array}{r}-0.006 \\
(0.010)\end{array}$ & $\begin{array}{r}-0.005 \\
(0.009)\end{array}$ & $\begin{array}{r}-0.006 \\
(0.010)\end{array}$ & $\begin{array}{r}-0.006 \\
(0.009)\end{array}$ & $\begin{array}{r}-0.005 \\
(0.010)\end{array}$ \\
\hline Floating* $\log (\mathrm{VXO})$ & & $\begin{array}{r}0.004 \\
(0.007)\end{array}$ & $\begin{array}{r}0.004 \\
(0.007)\end{array}$ & $\begin{array}{r}0.001 \\
(0.006)\end{array}$ & $\begin{array}{r}0.008 \\
(0.006)\end{array}$ & $\begin{array}{r}0.003 \\
(0.006)\end{array}$ & $\begin{array}{r}0.004 \\
(0.008)\end{array}$ \\
\hline lagged real GDP growth & $\begin{array}{r}-0.525^{* * *} \\
(0.138)\end{array}$ & $\begin{array}{r}-0.527^{* * *} \\
(0.138)\end{array}$ & $\begin{array}{r}-0.445^{* * *} \\
(0.107)\end{array}$ & $\begin{array}{r}-0.310^{* * *} \\
(0.093)\end{array}$ & $\begin{array}{r}-0.381^{* * *} \\
(0.094)\end{array}$ & $\begin{array}{r}-0.313^{* * *} \\
(0.092)\end{array}$ & $\begin{array}{r}-0.300^{* * *} \\
(0.090)\end{array}$ \\
\hline Lagged domestic credit growth & $\begin{array}{r}0.570^{* * *} \\
(0.041)\end{array}$ & $\begin{array}{r}0.574^{* * *} \\
(0.041)\end{array}$ & $\begin{array}{r}0.578^{* * *} \\
(0.041)\end{array}$ & $\begin{array}{r}0.567^{* * *} \\
(0.039)\end{array}$ & $\begin{array}{r}0.567^{* * *} \\
(0.040)\end{array}$ & $\begin{array}{r}0.568^{* * *} \\
(0.040)\end{array}$ & $\begin{array}{r}0.570^{* * *} \\
(0.040)\end{array}$ \\
\hline US T-bill rate & & & & $\begin{array}{l}-0.013^{*} \\
(0.007)\end{array}$ & & & \\
\hline Fixed*US T-bill rate & & & & $\begin{array}{r}0.000 \\
(0.003)\end{array}$ & & & \\
\hline Floating*US T-bill rate & & & & $\begin{array}{r}0.007^{* * *} \\
(0.002)\end{array}$ & & & \\
\hline US inflation rate & & & & $\begin{array}{r}-1.289^{* * *} \\
(0.318)\end{array}$ & & $\begin{array}{r}-1.300^{* * *} \\
(0.345)\end{array}$ & $\begin{array}{r}-1.537^{* * *} \\
(0.346)\end{array}$ \\
\hline Real US T-bill rate & & & $\begin{array}{r}0.687^{*} \\
(0.343)\end{array}$ & & & & \\
\hline Fixed* real US T-bill rate & & & $\begin{array}{r}-0.168 \\
(0.267)\end{array}$ & & & & \\
\hline Floating* real US T-bill rate & & & $\begin{array}{r}0.058 \\
(0.207)\end{array}$ & & & & \\
\hline Real shadow federal funds rate & & & & & $\begin{array}{r}1.552^{* * *} \\
(0.329)\end{array}$ & & \\
\hline Fixed*real shadow rate & & & & & $\begin{array}{r}-0.343 \\
(0.298)\end{array}$ & & \\
\hline Floating*real shadow rate & & & & & $\begin{array}{r}-0.784^{* * *} \\
(0.194)\end{array}$ & & \\
\hline Shadow federal funds rate & & & & & & $\begin{array}{r}-0.301 \\
(0.183)\end{array}$ & \\
\hline Fixed*shadow rate & & & & & & $\begin{array}{r}0.027 \\
(0.164)\end{array}$ & \\
\hline Floating*shadow rate & & & & & & $\begin{array}{l}0.263^{* *} \\
(0.103)\end{array}$ & \\
\hline Adjusted US FCI & & & & & & & $\begin{array}{r}0.012 \\
(0.007)\end{array}$ \\
\hline Fixed*adjusted FCI & & & & & & & $\begin{array}{r}-0.001 \\
(0.007)\end{array}$ \\
\hline Floating*adjusted FCI & & & & & & & $\begin{array}{r}0.002 \\
(0.004)\end{array}$ \\
\hline Observations & 3683 & 3683 & 3683 & 3683 & 3683 & 3683 & 3683 \\
\hline Number of groups & 16 & 16 & 16 & 16 & 16 & 16 & 16 \\
\hline Adjusted R-squared & 0.313 & 0.313 & 0.321 & 0.353 & 0.334 & 0.348 & 0.35 \\
\hline Country fixed-effect & YES & YES & YES & YES & YES & YES & YES \\
\hline
\end{tabular}

Note: Driscoll-Kraay standard errors in parentheses; ${ }^{* * *} \mathrm{p}<0.01,{ }^{* *} \mathrm{p}<0.05,{ }^{*} \mathrm{p}<0.1$. Dependent variable is the monthly real stock price growth rate. All regressions include a dummy variable for banking crisis, a dummy variable for global financial crisis and a time trend. Including the rate of change of the VXO index along with $\log (\mathrm{VXO})$, both coefficients remain negative and significant while the adjusted-R-squared improves in a range of 7-8\%, leaving all other results unchanged. Results are available from the authors upon request. Quarterly variables are lagged one quarter, monthly variables are lagged 1 month. 
Table 3. Real stock returns in EMEs - adding relevant country characteristics - 1995M12018M11

\begin{tabular}{|c|c|c|c|c|c|c|c|c|c|c|}
\hline & $\begin{array}{c}\text { (1) } \\
\text { DUSRFFR } \\
\end{array}$ & $\begin{array}{c}(2) \\
\Delta \text { USRFFR } \\
\text { EX REGIME } \\
\end{array}$ & $\begin{array}{c}3) \\
\text { USRFFR } \\
\text { USDEBT } \\
\end{array}$ & $\begin{array}{c}4) \\
\Delta \text { USRFFR } \\
\text { USTRADEINT } \\
\end{array}$ & $\begin{array}{c}(5) \\
\Delta \text { USANFCI } \\
\end{array}$ & $\begin{array}{c}(6) \\
\Delta U S A N F C I \\
\text { EX REGIME } \\
\end{array}$ & $\begin{array}{c}(7) \\
\triangle \text { USANFCI } \\
\text { USDEBT }\end{array}$ & $\begin{array}{c}(8) \\
\Delta \text { USANFCI } \\
\text { USTRADEINT }\end{array}$ & $\begin{array}{c}(9) \\
\log (V X O) \\
\text { CAGDP } \\
\end{array}$ & $\begin{array}{c}10) \\
\log (\mathrm{VXO}) \\
\text { USDEBT } \\
\end{array}$ \\
\hline Fixed regime & $\begin{array}{l}0.047^{* *} \\
(0.022)\end{array}$ & $\begin{array}{l}0.037 \\
(0.023)\end{array}$ & $\begin{array}{l}0.037 \\
(0.023)\end{array}$ & $\begin{array}{l}0.037 \\
(0.023)\end{array}$ & $\begin{array}{l}0.045^{* *} \\
(0.021)\end{array}$ & $\begin{array}{l}0.041^{*} \\
(0.020)\end{array}$ & $\begin{array}{l}0.041^{*} \\
(0.020)\end{array}$ & $\begin{array}{l}0.041^{*} \\
(0.020)\end{array}$ & $\begin{array}{l}0.034 \\
(0.020)\end{array}$ & $\begin{array}{l}0.032 \\
(0.020)\end{array}$ \\
\hline Floating regime & $\begin{array}{l}-0.009 \\
(0.017)\end{array}$ & $\begin{array}{l}-0.010 \\
(0.017)\end{array}$ & $\begin{array}{l}-0.010 \\
(0.017)\end{array}$ & $\begin{array}{l}-0.010 \\
(0.017)\end{array}$ & $\begin{array}{l}-0.009 \\
(0.017)\end{array}$ & $\begin{array}{l}-0.007 \\
(0.016)\end{array}$ & $\begin{array}{l}-0.007 \\
(0.016)\end{array}$ & $\begin{array}{l}-0.007 \\
(0.016)\end{array}$ & $\begin{array}{l}-0.015 \\
(0.020)\end{array}$ & $\begin{array}{l}-0.013 \\
(0.020)\end{array}$ \\
\hline $\log (\mathrm{VXO})$ & $\begin{array}{l}-0.024^{* *} \\
(0.008)\end{array}$ & $\begin{array}{l}-0.025^{* * *} \\
(0.008)\end{array}$ & $\begin{array}{l}-0.025^{* * *} \\
(0.008)\end{array}$ & $\begin{array}{l}-0.025^{* * *} \\
(0.008)\end{array}$ & $\begin{array}{l}-0.024^{* *} \\
(0.008)\end{array}$ & $\begin{array}{l}-0.024^{* *} \\
(0.008)\end{array}$ & $\begin{array}{l}-0.023^{* *} \\
(0.008)\end{array}$ & $\begin{array}{l}-0.023^{* *} \\
(0.008)\end{array}$ & $\begin{array}{l}-0.026^{* * *} \\
(0.008)\end{array}$ & $\begin{array}{l}-0.029^{* *} \\
(0.011)\end{array}$ \\
\hline$\Delta \log (\mathrm{VXO})$ & $\begin{array}{l}-0.133^{* * *} \\
(0.014)\end{array}$ & $\begin{array}{l}-0.133^{* * *} \\
(0.014)\end{array}$ & $\begin{array}{l}-0.133^{* * *} \\
(0.014)\end{array}$ & $\begin{array}{l}-0.133^{* * *} \\
(0.014)\end{array}$ & $\begin{array}{l}-0.124^{* * *} \\
(0.013)\end{array}$ & $\begin{array}{l}-0.125^{* * *} \\
(0.013)\end{array}$ & $\begin{array}{l}-0.125^{* * *} \\
(0.013)\end{array}$ & $\begin{array}{l}-0.125^{* * *} \\
(0.013)\end{array}$ & $\begin{array}{l}-0.124^{* * *} \\
(0.013)\end{array}$ & $\begin{array}{l}-0.124^{* * *} \\
(0.013)\end{array}$ \\
\hline Fixed regime* $\log (\mathrm{VXO})$ & $\begin{array}{l}-0.022^{* *} \\
(0.008)\end{array}$ & $\begin{array}{l}-0.018^{* *} \\
(0.008)\end{array}$ & $\begin{array}{l}-0.018^{* *} \\
(0.008)\end{array}$ & $\begin{array}{l}-0.018^{* *} \\
(0.008)\end{array}$ & $\begin{array}{l}-0.020^{* *} \\
(0.008)\end{array}$ & $\begin{array}{l}-0.019^{* *} \\
(0.007)\end{array}$ & $\begin{array}{l}-0.019^{* *} \\
(0.007)\end{array}$ & $\begin{array}{l}-0.019^{* *} \\
(0.007)\end{array}$ & $\begin{array}{l}-0.016^{* *} \\
(0.007)\end{array}$ & $\begin{array}{l}-0.015^{* *} \\
(0.007)\end{array}$ \\
\hline Floating regime* $\log (\mathrm{VXO})$ & $\begin{array}{l}-0.002 \\
(0.006)\end{array}$ & $\begin{array}{l}-0.002 \\
(0.006)\end{array}$ & $\begin{array}{l}-0.002 \\
(0.006)\end{array}$ & $\begin{array}{l}-0.002 \\
(0.006)\end{array}$ & $\begin{array}{l}-0.002 \\
(0.006)\end{array}$ & $\begin{array}{l}-0.003 \\
(0.006)\end{array}$ & $\begin{array}{l}-0.003 \\
(0.006)\end{array}$ & $\begin{array}{l}-0.003 \\
(0.006)\end{array}$ & $\begin{array}{l}0.002 \\
(0.007)\end{array}$ & $\begin{array}{l}0.001 \\
(0.007)\end{array}$ \\
\hline Lagged GDP growth & $\begin{array}{l}-0.293^{* *} \\
(0.105)\end{array}$ & $\begin{array}{l}-0.294^{* *} \\
(0.105)\end{array}$ & $\begin{array}{l}-0.294^{* *} \\
(0.105)\end{array}$ & $\begin{array}{l}-0.293^{* *} \\
(0.105)\end{array}$ & $\begin{array}{l}-0.241^{* *} \\
(0.097)\end{array}$ & $\begin{array}{l}-0.240^{* *} \\
(0.097)\end{array}$ & $\begin{array}{l}-0.239 * * \\
(0.097)\end{array}$ & $\begin{array}{l}-0.239^{* *} \\
(0.097)\end{array}$ & $\begin{array}{l}-0.260^{* *} \\
(0.094)\end{array}$ & $\begin{array}{l}-0.260^{* *} \\
(0.094)\end{array}$ \\
\hline Lagged domestic credit growth & $\begin{array}{l}0.401^{* * *} \\
(0.041)\end{array}$ & $\begin{array}{l}0.398^{* * *} \\
(0.042)\end{array}$ & $\begin{array}{l}0.398^{* * *} \\
(0.042)\end{array}$ & $\begin{array}{l}0.399^{* * *} \\
(0.042)\end{array}$ & $\begin{array}{l}0.393^{* * *} \\
(0.040)\end{array}$ & $\begin{array}{l}0.390^{* * *} \\
(0.039)\end{array}$ & $\begin{array}{l}0.390^{* * *} \\
(0.039)\end{array}$ & $\begin{array}{l}0.390^{* * *} \\
(0.039)\end{array}$ & $\begin{array}{l}0.387^{* * *} \\
(0.038)\end{array}$ & $\begin{array}{l}0.387^{* * *} \\
(0.038)\end{array}$ \\
\hline$\Delta$ real shadow federal funds rate & $\begin{array}{l}-0.696 \\
(0.507)\end{array}$ & $\begin{array}{l}-0.081 \\
(0.603)\end{array}$ & $\begin{array}{l}-0.403 \\
(0.800)\end{array}$ & $\begin{array}{l}-0.566 \\
(0.817)\end{array}$ & & & & & & \\
\hline Fixed ${ }^{*} \Delta$ real shadow rate & & $\begin{array}{l}-1.774^{* * *} \\
(0.590)\end{array}$ & $\begin{array}{l}-1.727^{* * *} \\
(0.564)\end{array}$ & $\begin{array}{l}-1.606^{* *} \\
(0.569)\end{array}$ & & & & & & \\
\hline Floating* $\Delta$ real shadow rate & & $\begin{array}{l}-0.276 \\
(0.384)\end{array}$ & $\begin{array}{l}-0.350 \\
(0.379)\end{array}$ & $\begin{array}{l}-0.438 \\
(0.368)\end{array}$ & & & & & & \\
\hline US\$DEBT /GDP*Areal shadow rate & & & $\begin{array}{l}3.537 \\
(4.030)\end{array}$ & $\begin{array}{l}2.399 \\
(4.131)\end{array}$ & & & & & & \\
\hline USTRADEINT* $\Delta$ real shadow rate & & & & $\begin{array}{l}7.570^{* *} \\
(2.980)\end{array}$ & & & & & & \\
\hline$\Delta$ adjusted US FCI & & & & & $\begin{array}{l}-0.034^{* * *} \\
(0.009)\end{array}$ & $\begin{array}{l}-0.035^{* * *} \\
(0.010)\end{array}$ & $\begin{array}{l}-0.030^{*} \\
(0.015)\end{array}$ & $\begin{array}{l}-0.033^{*} \\
(0.015)\end{array}$ & $\begin{array}{l}-0.033^{* * *} \\
(0.010)\end{array}$ & $\begin{array}{l}-0.033^{* * *} \\
(0.010)\end{array}$ \\
\hline$\Delta$ US inflation rate & & & & & $\begin{array}{l}0.217 \\
(0.499)\end{array}$ & $\begin{array}{l}0.222 \\
(0.500)\end{array}$ & $\begin{array}{l}0.224 \\
(0.501)\end{array}$ & $\begin{array}{l}0.223 \\
(0.501)\end{array}$ & $\begin{array}{l}0.256 \\
(0.494)\end{array}$ & $\begin{array}{l}0.253 \\
(0.493)\end{array}$ \\
\hline Fixed* $\Delta$ adj. US FCI & & & & & & $\begin{array}{l}-0.015 \\
(0.012)\end{array}$ & $\begin{array}{l}-0.017 \\
(0.012)\end{array}$ & $\begin{array}{l}-0.016 \\
(0.012)\end{array}$ & $\begin{array}{l}-0.019 \\
(0.012)\end{array}$ & $\begin{array}{l}-0.019 \\
(0.012)\end{array}$ \\
\hline Floating* $\Delta$ adj. US FCI & & & & & & $\begin{array}{l}0.011^{*} \\
(0.006)\end{array}$ & $\begin{array}{l}0.012^{*} \\
(0.006)\end{array}$ & $\begin{array}{l}0.010 \\
(0.006)\end{array}$ & $\begin{array}{l}0.010 \\
(0.006)\end{array}$ & $\begin{array}{l}0.010 \\
(0.006)\end{array}$ \\
\hline US\$DEBT /GDP* $\Delta$ adj. US FCI & & & & & & & $\begin{array}{l}-0.058 \\
(0.086)\end{array}$ & $\begin{array}{l}-0.076 \\
(0.087)\end{array}$ & & \\
\hline USTRADEINT* $\Delta$ adj. US FCI & & & & & & & & $\begin{array}{l}0.125^{* *} \\
(0.055)\end{array}$ & & \\
\hline $\mathrm{CA} / \mathrm{GDP} * \log (\mathrm{VXO})^{*}$ & & & & & & & & & $\begin{array}{l}0.179^{*} \\
(0.093)\end{array}$ & $\begin{array}{l}0.180^{*} \\
(0.093)\end{array}$ \\
\hline US\$DEBT /GDP*log(VXO) & & & & & & & & & & $\begin{array}{l}0.027 \\
(0.060)\end{array}$ \\
\hline Lagged $\Delta$ domestic policy rate & $\begin{array}{l}-0.110 \\
(0.176)\end{array}$ & $\begin{array}{l}-0.110 \\
(0.177)\end{array}$ & $\begin{array}{l}-0.111 \\
(0.177)\end{array}$ & $\begin{array}{l}-0.111 \\
(0.177)\end{array}$ & $\begin{array}{l}-0.119 \\
(0.178)\end{array}$ & $\begin{array}{l}-0.118 \\
(0.178)\end{array}$ & $\begin{array}{l}-0.117 \\
(0.178)\end{array}$ & $\begin{array}{l}-0.115 \\
(0.178)\end{array}$ & $\begin{array}{l}-0.128 \\
(0.179)\end{array}$ & $\begin{array}{l}-0.128 \\
(0.179)\end{array}$ \\
\hline log(US\$_FX_6) & $\begin{array}{l}-0.386^{* * *} \\
(0.129)\end{array}$ & $\begin{array}{l}-0.386^{* * *} \\
(0.129)\end{array}$ & $\begin{array}{l}-0.384^{* * *} \\
(0.129)\end{array}$ & $\begin{array}{l}-0.384^{* * *} \\
(0.129)\end{array}$ & $\begin{array}{l}-0.379^{* *} \\
(0.129)\end{array}$ & $\begin{array}{l}-0.381^{* * *} \\
(0.129)\end{array}$ & $\begin{array}{l}-0.381^{* * *} \\
(0.129)\end{array}$ & $\begin{array}{l}-0.381^{* * *} \\
(0.129)\end{array}$ & $\begin{array}{l}-0.377^{* *} \\
(0.128)\end{array}$ & $\begin{array}{l}-0.377^{* *} \\
(0.128)\end{array}$ \\
\hline Lagged oil inflation & $\begin{array}{l}-0.018 \\
(0.021)\end{array}$ & $\begin{array}{l}-0.018 \\
(0.021)\end{array}$ & $\begin{array}{l}-0.018 \\
(0.021)\end{array}$ & $\begin{array}{l}-0.018 \\
(0.021)\end{array}$ & $\begin{array}{l}-0.019 \\
(0.020)\end{array}$ & $\begin{array}{l}-0.019 \\
(0.020)\end{array}$ & $\begin{array}{l}-0.019 \\
(0.020)\end{array}$ & $\begin{array}{l}-0.019 \\
(0.020)\end{array}$ & $\begin{array}{l}-0.020 \\
(0.020)\end{array}$ & $\begin{array}{l}-0.020 \\
(0.020)\end{array}$ \\
\hline Lagged CA/GDP & $\begin{array}{l}0.245^{* * *} \\
(0.042)\end{array}$ & $\begin{array}{l}0.247^{* * *} \\
(0.041)\end{array}$ & $\begin{array}{l}0.247^{* * *} \\
(0.041)\end{array}$ & $\begin{array}{l}0.247^{* * *} \\
(0.042)\end{array}$ & $\begin{array}{l}0.243^{* * *} \\
(0.040)\end{array}$ & $\begin{array}{l}0.244^{* * *} \\
(0.040)\end{array}$ & $\begin{array}{l}0.244^{* * *} \\
(0.040)\end{array}$ & $\begin{array}{l}0.244^{* * *} \\
(0.040)\end{array}$ & $\begin{array}{l}-0.287 \\
(0.265)\end{array}$ & $\begin{array}{l}-0.288 \\
(0.266)\end{array}$ \\
\hline Financial integration & $\begin{array}{l}0.029^{* * *} \\
(0.008)\end{array}$ & $\begin{array}{l}0.028^{* * *} \\
(0.008)\end{array}$ & $\begin{array}{l}0.028^{* * *} \\
(0.008)\end{array}$ & $\begin{array}{l}0.028^{* * *} \\
(0.008)\end{array}$ & $\begin{array}{l}0.028^{* * *} \\
(0.008)\end{array}$ & $\begin{array}{l}0.028^{* * *} \\
(0.008)\end{array}$ & $\begin{array}{l}0.028^{* * *} \\
(0.008)\end{array}$ & $\begin{array}{l}0.028^{* * *} \\
(0.008)\end{array}$ & $\begin{array}{l}0.021^{* * *} \\
(0.007)\end{array}$ & $\begin{array}{l}0.021 * * * \\
(0.007)\end{array}$ \\
\hline Lagged portfolio liability flows/GDP & $\begin{array}{l}-0.057 \\
(0.074)\end{array}$ & $\begin{array}{l}-0.054 \\
(0.074)\end{array}$ & $\begin{array}{l}-0.056 \\
(0.075)\end{array}$ & $\begin{array}{l}-0.057 \\
(0.075)\end{array}$ & $\begin{array}{l}-0.032 \\
(0.073)\end{array}$ & $\begin{array}{l}-0.032 \\
(0.073)\end{array}$ & $\begin{array}{l}-0.031 \\
(0.073)\end{array}$ & $\begin{array}{l}-0.029 \\
(0.073)\end{array}$ & $\begin{array}{l}-0.064 \\
(0.073)\end{array}$ & $\begin{array}{l}-0.064 \\
(0.073)\end{array}$ \\
\hline Lagged US\$DEBT/GDP & $\begin{array}{l}-0.070 \\
(0.050)\end{array}$ & $\begin{array}{l}-0.069 \\
(0.050)\end{array}$ & $\begin{array}{l}-0.067 \\
(0.050)\end{array}$ & $\begin{array}{l}-0.067 \\
(0.049)\end{array}$ & $\begin{array}{l}-0.053 \\
(0.049)\end{array}$ & $\begin{array}{l}-0.053 \\
(0.049)\end{array}$ & $\begin{array}{l}-0.052 \\
(0.049)\end{array}$ & $\begin{array}{l}-0.050 \\
(0.049)\end{array}$ & $\begin{array}{l}-0.062 \\
(0.044)\end{array}$ & $\begin{array}{l}-0.137 \\
(0.159)\end{array}$ \\
\hline Lagged W_TRADE_INT & $\begin{array}{l}-0.072^{*} \\
(0.038)\end{array}$ & $\begin{array}{l}-0.070^{*} \\
(0.038)\end{array}$ & $\begin{array}{l}-0.070^{*} \\
(0.038)\end{array}$ & $\begin{array}{l}-0.070^{*} \\
(0.038)\end{array}$ & $\begin{array}{l}-0.074^{*} \\
(0.039)\end{array}$ & $\begin{array}{l}-0.071^{*} \\
(0.038)\end{array}$ & $\begin{array}{l}-0.071^{*} \\
(0.039)\end{array}$ & $\begin{array}{l}-0.071^{*} \\
(0.039)\end{array}$ & & \\
\hline Lagged US_TRADE_INT & $\begin{array}{l}0.174 \\
(0.168)\end{array}$ & $\begin{array}{l}0.168 \\
(0.167)\end{array}$ & $\begin{array}{l}0.167 \\
(0.167)\end{array}$ & $\begin{array}{l}0.168 \\
(0.168)\end{array}$ & $\begin{array}{l}0.118 \\
(0.169)\end{array}$ & $\begin{array}{l}0.114 \\
(0.168)\end{array}$ & $\begin{array}{l}0.111 \\
(0.169)\end{array}$ & $\begin{array}{l}0.110 \\
(0.168)\end{array}$ & & \\
\hline Lagged foreign exchange reserve/GDP & $\begin{array}{l}-0.037 \\
(0.029)\end{array}$ & $\begin{array}{l}-0.037 \\
(0.028)\end{array}$ & $\begin{array}{l}-0.036 \\
(0.028)\end{array}$ & $\begin{array}{l}-0.036 \\
(0.028)\end{array}$ & $\begin{array}{l}-0.042 \\
(0.028)\end{array}$ & $\begin{array}{l}-0.041 \\
(0.029)\end{array}$ & $\begin{array}{l}-0.042 \\
(0.029)\end{array}$ & $\begin{array}{l}-0.042 \\
(0.029)\end{array}$ & $\begin{array}{l}-0.052^{*} \\
(0.028)\end{array}$ & $\begin{array}{l}-0.051^{*} \\
(0.028)\end{array}$ \\
\hline Observations & 3018 & 3018 & 3018 & 3018 & 3018 & 3018 & 3018 & 3018 & 3045 & 3045 \\
\hline Number of groups & 16 & 16 & 16 & 16 & 16 & 16 & 16 & 16 & 16 & 16 \\
\hline Adjusted R-squared & 0.416 & 0.418 & 0.418 & 0.418 & 0.425 & 0.426 & 0.426 & 0.426 & 0.425 & 0.425 \\
\hline Country fixed effects & YES & YES & YES & YES & YES & YES & YES & YES & YES & YES \\
\hline
\end{tabular}

Note: Driscoll-Kraay standard errors in parentheses; ${ }^{* * *} \mathrm{p}<0.01,{ }^{* *} \mathrm{p}<0.05,{ }^{*} \mathrm{p}<0.1$. Dependent variable is the monthly real stock price growth rate. All regressions include a dummy variable for banking crisis, a dummy variable for global financial crisis and a time trend. Delta stands for first difference of the indicated variable. Quarterly variables are lagged one quarter, monthly variables are lagged 1 month. 
Table 4. Sovereign spreads and short-term rates in EMEs, 1995M1-2018M1

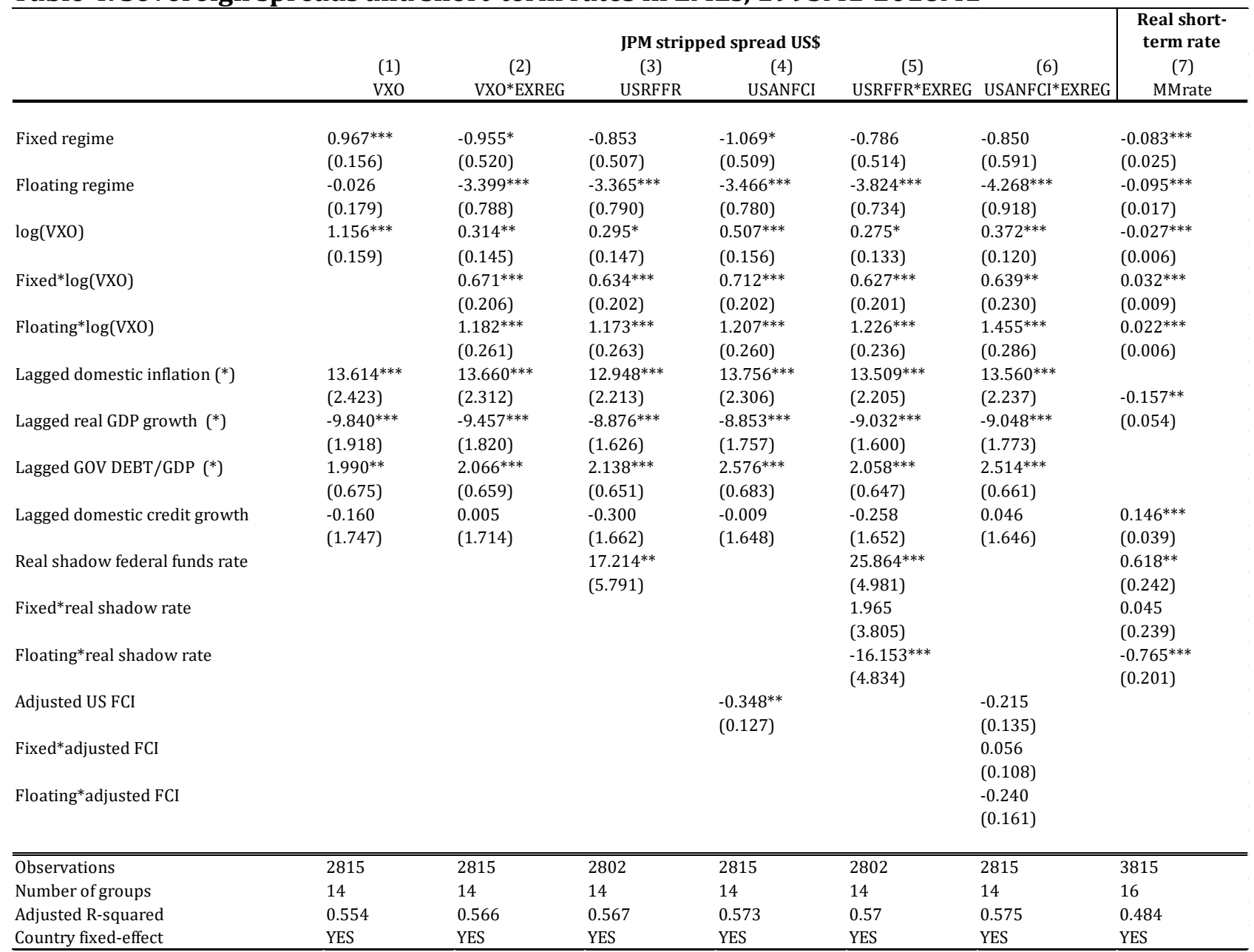

Note: Driscoll-Kraay standard errors in parentheses; ${ }^{* * *} \mathrm{p}<0.01,{ }^{* *} \mathrm{p}<0.05,{ }^{*} \mathrm{p}<0.1$. Column (1)-(6): Dependent variable is the monthly average of sovereign spread on US\$ bonds, in basis points. The variables indicated with an asterisk are taken as differentials with respect to the corresponding US values in columns (1), (2), (4) and (6). Column (7): Dependent variable is the short-term money market rate. All regressions include a dummy variable for banking crisis, a dummy variable for global financial crisis and a time trend. Quarterly variables are lagged one quarter, monthly variables are lagged 1 month. 
Table 5. Sovereign spreads (first difference) in EMEs- adding relevant country characteristics- 1995M1-2018M11

\begin{tabular}{|c|c|c|c|c|c|c|c|c|c|c|}
\hline & $\begin{array}{c}(1) \\
\triangle \mathrm{VXO}{ }^{*} \mathrm{CAGDP} \\
\end{array}$ & $\begin{array}{c}(2) \\
\Delta V X 0^{*} \\
\text { USDEBT } \\
\end{array}$ & $\begin{array}{c}(3) \\
\Delta \text { VXO* } \\
\text { USTRADEINT } \\
\end{array}$ & $\begin{array}{c}(4) \\
\Delta \text { VXO* } \\
\text { WTRADEINT } \\
\end{array}$ & $\begin{array}{c}(5) \\
\triangle V V_{0} * A L L \\
\end{array}$ & $\begin{array}{c}(6) \\
\triangle V X 0^{*} \text { CAGDP } \\
\end{array}$ & $\begin{array}{c}(7) \\
\Delta V X 0^{*} \\
\text { USDEBT } \\
\end{array}$ & $\begin{array}{c}(8) \\
\Delta \text { VXO* } \\
\text { USTRADEINT } \\
\end{array}$ & $\begin{array}{c}(9) \\
\Delta \text { VXO* } \\
\text { WTRADEINT } \\
\end{array}$ & $\begin{array}{c}(10) \\
\triangle V X X 0^{*} A L L \\
\end{array}$ \\
\hline Fixed regime & $\begin{array}{l}0.148^{* *} \\
(0.051)\end{array}$ & $\begin{array}{l}0.143^{* *} \\
(0.050)\end{array}$ & $\begin{array}{l}0.145^{* *} \\
(0.051)\end{array}$ & $\begin{array}{l}0.137^{* *} \\
(0.050)\end{array}$ & $\begin{array}{l}0.138^{* *} \\
(0.050)\end{array}$ & $\begin{array}{l}0.142^{* *} \\
(0.050)\end{array}$ & $\begin{array}{l}0.137^{* *} \\
(0.049)\end{array}$ & $\begin{array}{l}0.138^{* *} \\
(0.050)\end{array}$ & $\begin{array}{l}0.133^{* *} \\
(0.048)\end{array}$ & $\begin{array}{l}0.134^{* *} \\
(0.049)\end{array}$ \\
\hline Floating regime & $\begin{array}{l}0.021 \\
(0.041)\end{array}$ & $\begin{array}{l}0.016 \\
(0.041)\end{array}$ & $\begin{array}{l}0.013 \\
(0.041)\end{array}$ & $\begin{array}{l}0.016 \\
(0.042)\end{array}$ & $\begin{array}{l}0.019 \\
(0.042)\end{array}$ & $\begin{array}{l}0.019 \\
(0.040)\end{array}$ & $\begin{array}{l}0.014 \\
(0.040)\end{array}$ & $\begin{array}{l}0.011 \\
(0.039)\end{array}$ & $\begin{array}{l}0.008 \\
(0.040)\end{array}$ & $\begin{array}{l}0.012 \\
(0.041)\end{array}$ \\
\hline$\Delta \log (\mathrm{VXO})$ & $\begin{array}{l}0.672^{* * *} \\
(0.096)\end{array}$ & $\begin{array}{l}0.476^{* * *} \\
(0.077)\end{array}$ & $\begin{array}{l}0.746^{* * *} \\
(0.117)\end{array}$ & $\begin{array}{l}1.272^{* * *} \\
(0.240)\end{array}$ & $\begin{array}{l}0.975^{* * *} \\
(0.174)\end{array}$ & $\begin{array}{l}1.271^{* * *} \\
(0.089)\end{array}$ & $\begin{array}{l}1.111^{* * *} \\
(0.084)\end{array}$ & $\begin{array}{l}1.367^{* * *} \\
(0.105)\end{array}$ & $\begin{array}{l}1.876^{* * *} \\
(0.235)\end{array}$ & $\begin{array}{l}1.587^{* * *} \\
(0.165)\end{array}$ \\
\hline$\Delta$ adjusted US FCI & $\begin{array}{l}0.234^{* *} \\
(0.100)\end{array}$ & $\begin{array}{l}0.239^{* *} \\
(0.093)\end{array}$ & $\begin{array}{l}0.231^{\text {** }} \\
(0.093)\end{array}$ & $\begin{array}{l}0.344^{* * *} \\
(0.083)\end{array}$ & $\begin{array}{l}0.372^{* * *} \\
(0.082)\end{array}$ & & & & & \\
\hline Fixed* $\Delta$ adj. US FCI & $\begin{array}{l}0.193 \\
(0.133)\end{array}$ & $\begin{array}{l}0.154 \\
(0.119)\end{array}$ & $\begin{array}{l}0.138 \\
(0.115)\end{array}$ & $\begin{array}{l}0.029 \\
(0.107)\end{array}$ & $\begin{array}{l}0.041 \\
(0.102)\end{array}$ & & & & & \\
\hline Floating* $\Delta$ adj. US FCI & $\begin{array}{l}0.173 \\
(0.140)\end{array}$ & $\begin{array}{l}0.198 \\
(0.138)\end{array}$ & $\begin{array}{l}0.208 \\
(0.134)\end{array}$ & $\begin{array}{l}0.062 \\
(0.096)\end{array}$ & $\begin{array}{l}0.034 \\
(0.100)\end{array}$ & & & & & \\
\hline $\mathrm{CA} / \mathrm{GDP}^{*} \Delta \log (\mathrm{VXO})$ & $\begin{array}{l}-0.036^{* * *} \\
(0.008)\end{array}$ & & & & $\begin{array}{l}-0.012^{*} \\
(0.006)\end{array}$ & $\begin{array}{l}-0.031^{* * *} \\
(0.009)\end{array}$ & & & & $\begin{array}{l}-0.014^{*} \\
(0.007)\end{array}$ \\
\hline US\$DEBT/GDP* $\log (\mathrm{VXO})$ & & $\begin{array}{l}2.154^{* *} \\
(0.768)\end{array}$ & & & $\begin{array}{l}4.403^{* * * *} \\
(1.332)\end{array}$ & & $\begin{array}{l}1.957^{* *} \\
(0.772)\end{array}$ & & & $\begin{array}{l}4.847^{* * *} \\
(1.422)\end{array}$ \\
\hline US_TRADE_INT* $\Delta \log (V X O)$ & & & $\begin{array}{l}-1.160^{*} \\
(0.568)\end{array}$ & & $\begin{array}{l}-1.825^{* *} \\
(0.725)\end{array}$ & & & $\begin{array}{l}-1.440^{* * *} \\
(0.442)\end{array}$ & & $\begin{array}{l}-1.596^{* *} \\
(0.605)\end{array}$ \\
\hline W_TRADE_INT* $\Delta \log (V X O)$ & & & & $\begin{array}{l}-1.834^{* * * *} \\
(0.478)\end{array}$ & $\begin{array}{l}-2.132^{* * *} \\
(0.563)\end{array}$ & & & & $\begin{array}{l}-1.825^{* * * *} \\
(0.514)\end{array}$ & $\begin{array}{l}-2.282^{* * *} \\
(0.608)\end{array}$ \\
\hline$\Delta$ res adj. US FCI & & & & & & $\begin{array}{l}1.123^{* * *} \\
(0.111)\end{array}$ & $\begin{array}{l}1.182^{* * *} \\
(0.106)\end{array}$ & $\begin{array}{l}1.220^{* * * *} \\
(0.113)\end{array}$ & $\begin{array}{l}1.019^{* * * *} \\
(0.125)\end{array}$ & $\begin{array}{l}0.876^{* * *} \\
(0.143)\end{array}$ \\
\hline Fixed $* \Delta$ res adj. US FCI & & & & & & $\begin{array}{l}-0.279 \\
(0.206)\end{array}$ & $\begin{array}{l}-0.309 \\
(0.202)\end{array}$ & $\begin{array}{l}-0.280 \\
(0.200)\end{array}$ & $\begin{array}{l}-0.195 \\
(0.168)\end{array}$ & $\begin{array}{l}-0.125 \\
(0.156)\end{array}$ \\
\hline Floating* $\Delta$ res adj. US FCI & & & & & & $\begin{array}{l}-0.315^{*} \\
(0.150)\end{array}$ & $\begin{array}{l}-0.360^{* *} \\
(0.139)\end{array}$ & $\begin{array}{l}-0.457^{* * *} \\
(0.151)\end{array}$ & $\begin{array}{l}-0.133 \\
(0.125)\end{array}$ & $\begin{array}{l}0.141 \\
(0.158)\end{array}$ \\
\hline Lagged $\triangle$ NEER & $\begin{array}{l}-1.383^{* *} \\
(0.625)\end{array}$ & $\begin{array}{l}-1.368^{* *} \\
(0.617)\end{array}$ & $\begin{array}{l}-1.462^{* *} \\
(0.641)\end{array}$ & $\begin{array}{l}-1.394^{* *} \\
(0.615)\end{array}$ & $\begin{array}{l}-1.349 * * \\
(0.596)\end{array}$ & $\begin{array}{l}-1.180^{*} \\
(0.636)\end{array}$ & $\begin{array}{l}-1.167^{*} \\
(0.629)\end{array}$ & $\begin{array}{l}-1.289^{*} \\
(0.651)\end{array}$ & $\begin{array}{l}-1.182^{*} \\
(0.636)\end{array}$ & $\begin{array}{l}-1.079 \\
(0.618)\end{array}$ \\
\hline$\Delta \log \left(\mathrm{USS}_{-} \mathrm{FX}_{-} 6\right)$ & $\begin{array}{l}0.257 \\
(0.476)\end{array}$ & $\begin{array}{l}0.222 \\
(0.487)\end{array}$ & $\begin{array}{l}0.245 \\
(0.489)\end{array}$ & $\begin{array}{l}0.246 \\
(0.481)\end{array}$ & $\begin{array}{l}0.233 \\
(0.479)\end{array}$ & $\begin{array}{l}0.265 \\
(0.481)\end{array}$ & $\begin{array}{l}0.230 \\
(0.494)\end{array}$ & $\begin{array}{l}0.240 \\
(0.497)\end{array}$ & $\begin{array}{l}0.251 \\
(0.488)\end{array}$ & $\begin{array}{l}0.257 \\
(0.482)\end{array}$ \\
\hline$\Delta U S$ inflation rate & $\begin{array}{l}-4.034^{*} \\
(2.274)\end{array}$ & $\begin{array}{l}-4.419^{*} \\
(2.295)\end{array}$ & $\begin{array}{l}-4.224^{*} \\
(2.290)\end{array}$ & $\begin{array}{l}-4.226^{*} \\
(2.295)\end{array}$ & $\begin{array}{l}-4.493^{*} \\
(2.329)\end{array}$ & $\begin{array}{l}-1.385 \\
(2.169)\end{array}$ & $\begin{array}{l}-1.688 \\
(2.200)\end{array}$ & $\begin{array}{l}-1.573 \\
(2.203)\end{array}$ & $\begin{array}{l}-1.490 \\
(2.207)\end{array}$ & $\begin{array}{l}-1.580 \\
(2.229)\end{array}$ \\
\hline Lagged $\Delta$ domestic inflation rate & $\begin{array}{l}-1.432 \\
(1.877)\end{array}$ & $\begin{array}{l}-1.562 \\
(1.862)\end{array}$ & $\begin{array}{l}-1.442 \\
(1.868)\end{array}$ & $\begin{array}{l}-1.345 \\
(1.847)\end{array}$ & $\begin{array}{l}-1.306 \\
(1.834)\end{array}$ & $\begin{array}{l}-1.738 \\
(1.864)\end{array}$ & $\begin{array}{l}-1.834 \\
(1.856)\end{array}$ & $\begin{array}{l}-1.677 \\
(1.862)\end{array}$ & $\begin{array}{l}-1.708 \\
(1.836)\end{array}$ & $\begin{array}{l}-1.802 \\
(1.826)\end{array}$ \\
\hline Lagged $\Delta$ domestic policy rate & $\begin{array}{l}0.015 \\
(0.021)\end{array}$ & $\begin{array}{l}0.015 \\
(0.021)\end{array}$ & $\begin{array}{l}0.015 \\
(0.021)\end{array}$ & $\begin{array}{l}0.016 \\
(0.021)\end{array}$ & $\begin{array}{l}0.015 \\
(0.021)\end{array}$ & $\begin{array}{l}0.016 \\
(0.021)\end{array}$ & $\begin{array}{l}0.016 \\
(0.021)\end{array}$ & $\begin{array}{l}0.015 \\
(0.022)\end{array}$ & $\begin{array}{l}0.018 \\
(0.022)\end{array}$ & $\begin{array}{l}0.017 \\
(0.021)\end{array}$ \\
\hline Lagged oil inflation & $\begin{array}{l}-0.206^{*} \\
(0.111)\end{array}$ & $\begin{array}{l}-0.200^{*} \\
(0.109)\end{array}$ & $\begin{array}{l}-0.203^{*} \\
(0.112)\end{array}$ & $\begin{array}{l}-0.207^{*} \\
(0.111)\end{array}$ & $\begin{array}{l}-0.207^{*} \\
(0.111)\end{array}$ & $\begin{array}{l}-0.084 \\
(0.111)\end{array}$ & $\begin{array}{l}-0.074 \\
(0.110)\end{array}$ & $\begin{array}{l}-0.076 \\
(0.112)\end{array}$ & $\begin{array}{l}-0.082 \\
(0.112)\end{array}$ & $\begin{array}{l}-0.081 \\
(0.112)\end{array}$ \\
\hline Lagged domestic real GDP growth $\left({ }^{*}\right)$ & $\begin{array}{l}0.430 \\
(0.398)\end{array}$ & $\begin{array}{l}0.380 \\
(0.394)\end{array}$ & $\begin{array}{l}0.524 \\
(0.414)\end{array}$ & $\begin{array}{l}0.479 \\
(0.408)\end{array}$ & $\begin{array}{l}0.415 \\
(0.406)\end{array}$ & $\begin{array}{l}0.185 \\
(0.374)\end{array}$ & $\begin{array}{l}0.128 \\
(0.371)\end{array}$ & $\begin{array}{l}0.253 \\
(0.391)\end{array}$ & $\begin{array}{l}0.275 \\
(0.405)\end{array}$ & $\begin{array}{l}0.221 \\
(0.391)\end{array}$ \\
\hline Lagged GOV DEBT/GDP $(*)$ & $\begin{array}{l}0.633^{*} \\
(0.317)\end{array}$ & $\begin{array}{l}0.610^{*} \\
(0.308)\end{array}$ & $\begin{array}{l}0.660^{*} \\
(0.323)\end{array}$ & $\begin{array}{l}0.673^{*} \\
(0.329)\end{array}$ & $\begin{array}{l}0.636^{*} \\
(0.323)\end{array}$ & $\begin{array}{l}0.779^{* *} \\
(0.320)\end{array}$ & $\begin{array}{l}0.761^{* *} \\
(0.311)\end{array}$ & $\begin{array}{l}0.809^{* *} \\
(0.326)\end{array}$ & $\begin{array}{l}0.789^{* *} \\
(0.327)\end{array}$ & $\begin{array}{l}0.739^{* *} \\
(0.320)\end{array}$ \\
\hline Lagged domestic credit growth & $\begin{array}{l}0.523 \\
(0.332)\end{array}$ & $\begin{array}{l}0.535 \\
(0.331)\end{array}$ & $\begin{array}{l}0.510 \\
(0.332)\end{array}$ & $\begin{array}{l}0.468 \\
(0.330)\end{array}$ & $\begin{array}{l}0.466 \\
(0.330)\end{array}$ & $\begin{array}{l}0.580 \\
(0.334)\end{array}$ & $\begin{array}{l}0.599^{*} \\
(0.332)\end{array}$ & $\begin{array}{l}0.583 \\
(0.331)\end{array}$ & $\begin{array}{l}0.525 \\
(0.333)\end{array}$ & $\begin{array}{l}0.510 \\
(0.338)\end{array}$ \\
\hline Lagged foreign exchange reserve/GDP & $\begin{array}{l}0.194 \\
(0.164)\end{array}$ & $\begin{array}{l}0.205 \\
(0.166)\end{array}$ & $\begin{array}{l}0.181 \\
(0.168)\end{array}$ & $\begin{array}{l}0.173 \\
(0.160)\end{array}$ & $\begin{array}{l}0.202 \\
(0.159)\end{array}$ & $\begin{array}{l}0.275 \\
(0.172)\end{array}$ & $\begin{array}{l}0.285 \\
(0.172)\end{array}$ & $\begin{array}{l}0.266 \\
(0.171)\end{array}$ & $\begin{array}{l}0.235 \\
(0.156)\end{array}$ & $\begin{array}{l}0.251 \\
(0.162)\end{array}$ \\
\hline Financial integration & $\begin{array}{l}-0.097^{* *} \\
(0.040)\end{array}$ & $\begin{array}{l}-0.096 * * \\
(0.040)\end{array}$ & $\begin{array}{l}-0.104^{* *} \\
(0.043)\end{array}$ & $\begin{array}{l}-0.113^{* *} \\
(0.044)\end{array}$ & $\begin{array}{l}-0.119^{* *} \\
(0.045)\end{array}$ & $\begin{array}{l}-0.097^{* *} \\
(0.042)\end{array}$ & $\begin{array}{l}-0.096 * * \\
(0.041)\end{array}$ & $\begin{array}{l}-0.103^{* *} \\
(0.043)\end{array}$ & $\begin{array}{l}-0.098^{* *} \\
(0.040)\end{array}$ & $\begin{array}{l}-0.103^{* *} \\
(0.043)\end{array}$ \\
\hline Lagged portfolio liability flows/GDP & $\begin{array}{l}4.309^{* * *} \\
(1.358)\end{array}$ & $\begin{array}{l}4.014^{* *} \\
(1.363)\end{array}$ & $\begin{array}{l}3.872^{* *} \\
(1.399)\end{array}$ & $\begin{array}{l}4.010^{* *} \\
(1.375)\end{array}$ & $\begin{array}{l}3.831^{* *} \\
(1.380)\end{array}$ & $\begin{array}{l}3.854^{* *} \\
(1.308)\end{array}$ & $\begin{array}{l}3.565^{* *} \\
(1.295)\end{array}$ & $\begin{array}{l}3.359^{* *} \\
(1.337)\end{array}$ & $\begin{array}{l}3.663^{* *} \\
(1.347)\end{array}$ & $\begin{array}{l}3.614^{* *} \\
(1.343)\end{array}$ \\
\hline Lagged CA/GDP & $\begin{array}{l}-0.461^{*} \\
(0.219)\end{array}$ & $\begin{array}{l}-0.485^{* *} \\
(0.218)\end{array}$ & $\begin{array}{l}-0.477^{* *} \\
(0.212)\end{array}$ & $\begin{array}{l}-0.462^{* *} \\
(0.213)\end{array}$ & $\begin{array}{l}-0.453^{* *} \\
(0.210)\end{array}$ & $\begin{array}{l}-0.362 \\
(0.221)\end{array}$ & $\begin{array}{l}-0.384 \\
(0.219)\end{array}$ & $\begin{array}{l}-0.381^{*} \\
(0.211)\end{array}$ & $\begin{array}{l}-0.401^{*} \\
(0.208)\end{array}$ & $\begin{array}{l}-0.394^{*} \\
(0.208)\end{array}$ \\
\hline Lagged US\$DEBT/GDP & $\begin{array}{l}0.287 \\
(0.436)\end{array}$ & $\begin{array}{l}0.313 \\
(0.427)\end{array}$ & $\begin{array}{l}0.380 \\
(0.469)\end{array}$ & $\begin{array}{l}0.414 \\
(0.469)\end{array}$ & $\begin{array}{l}0.469 \\
(0.458)\end{array}$ & $\begin{array}{l}0.227 \\
(0.432)\end{array}$ & $\begin{array}{l}0.244 \\
(0.423)\end{array}$ & $\begin{array}{l}0.311 \\
(0.458)\end{array}$ & $\begin{array}{l}0.322 \\
(0.457)\end{array}$ & $\begin{array}{l}0.378 \\
(0.452)\end{array}$ \\
\hline $\begin{array}{l}\text { US_TRADE_INT } \\
\text { W_TRADEINT }\end{array}$ & & & $\begin{array}{l}-1.229^{*} \\
(0.692)\end{array}$ & $\begin{array}{l}-1.499^{*} \\
(0.816) \\
0.101 \\
(0.182)\end{array}$ & $\begin{array}{l}-1.501^{*} \\
(0.792) \\
0.110 \\
(0.177)\end{array}$ & & & $\begin{array}{l}-1.144 \\
(0.682)\end{array}$ & $\begin{array}{l}-1.252^{*} \\
(0.679)\end{array}$ & $\begin{array}{l}-1.290 \\
(0.817) \\
0.012 \\
(0.181)\end{array}$ \\
\hline Observations & 2408 & 2417 & 2381 & 2381 & 2381 & 2408 & 2417 & 2381 & 2381 & 2381 \\
\hline Number of groups & 14 & 14 & 14 & 14 & 14 & 14 & 14 & 14 & 14 & 14 \\
\hline Adjusted R-squared & 0.291 & 0.289 & 0.288 & 0.312 & 0.327 & 0.301 & 0.300 & 0.300 & 0.323 & 0.339 \\
\hline Country fixed-effect & YES & YES & YES & YES & YES & YES & YES & YES & YES & YES \\
\hline
\end{tabular}

Note: Driscoll-Kraay standard errors in parentheses; ${ }^{* * *} \mathrm{p}<0.01,{ }^{* *} \mathrm{p}<0.05,{ }^{*} \mathrm{p}<0.1$. Dependent variable is the first difference of the monthly average of spread on US dollar denominated sovereign bonds, in basis points. All regressions include a dummy variable for banking crisis, a dummy variable for global financial crisis. $\Delta$ stands for first difference of the indicated variable. The variables indicated with an asterisk are taken as differentials with respect to the corresponding US values. Quarterly variables are lagged one quarter, monthly variables are lagged 1 month. In columns (6) to (10) we consider the change of the portion of FCI orthogonal to the VXO ( $\triangle$ res adj. US FCI). 
Table 6. Real credit growth: the role of the exchange rate regime

\begin{tabular}{|c|c|c|c|c|c|}
\hline & $(1)$ & $(2)$ & (3) & $(4)$ & $(5)$ \\
\hline Fixed regime & $\begin{array}{c}0.122 \\
(0.063)^{* * *}\end{array}$ & $\begin{array}{c}0.215 \\
(0.068)^{* *}\end{array}$ & $\begin{array}{c}0.239 \\
(0.060)^{* * *}\end{array}$ & $\begin{array}{c}0.160 \\
(0.066)^{* *}\end{array}$ & $\begin{array}{c}0.162 \\
(0.058)^{* *}\end{array}$ \\
\hline Floating regime & $\begin{array}{c}0.668 \\
(0.393)\end{array}$ & $\begin{array}{c}0.689 \\
(0.336)^{*}\end{array}$ & $\begin{array}{c}0.207 \\
(0.158)\end{array}$ & $\begin{array}{c}0.722 \\
(0.381)^{*}\end{array}$ & $\begin{array}{c}0.198 \\
(0.111)^{*}\end{array}$ \\
\hline $\log (\mathrm{VXO})$ & $\begin{array}{c}-0.007 \\
(0.003)^{* *}\end{array}$ & $\begin{array}{c}-0.007 \\
(0.002)^{* *}\end{array}$ & $\begin{array}{c}-0.006 \\
(0.002)^{* *}\end{array}$ & $\begin{array}{c}-0.008 \\
(0.003)^{* *}\end{array}$ & $\begin{array}{c}-0.006 \\
(0.003)^{*}\end{array}$ \\
\hline Fixed* $\log (\mathrm{VXO})$ & $\begin{array}{c}0.000 \\
(0.003)\end{array}$ & $\begin{array}{c}-0.001 \\
(0.003)\end{array}$ & $\begin{array}{c}-0.001 \\
(0.003)\end{array}$ & $\begin{array}{c}0.001 \\
(0.004)\end{array}$ & $\begin{array}{c}0.003 \\
(0.004)\end{array}$ \\
\hline Floating * $\log (\mathrm{VXO})$ & $\begin{array}{c}-0.051 \\
(0.043)\end{array}$ & $\begin{array}{l}-0.053 \\
(0.042)\end{array}$ & $\begin{array}{c}-0.023 \\
(0.009)^{* *}\end{array}$ & $\begin{array}{c}-0.044 \\
(0.039)\end{array}$ & $\begin{array}{c}-0.031 \\
(0.009)^{* * *}\end{array}$ \\
\hline Adjusted US FCI & $\begin{array}{c}-0.002 \\
(0.003)\end{array}$ & $\begin{array}{c}0.000 \\
(0.003)\end{array}$ & $\begin{array}{c}-0.005 \\
(0.003)\end{array}$ & $\begin{array}{c}0.000 \\
(0.003)\end{array}$ & $\begin{array}{c}-0.006 \\
(0.003)^{*}\end{array}$ \\
\hline Fixed *Adjusted US FCI & $\begin{array}{c}0.005 \\
(0.004)\end{array}$ & $\begin{array}{c}0.004 \\
(0.004)\end{array}$ & $\begin{array}{c}0.008 \\
(0.003)^{* *}\end{array}$ & $\begin{array}{c}0.005 \\
(0.004)\end{array}$ & $\begin{array}{c}0.009 \\
(0.003)^{* *}\end{array}$ \\
\hline Floating*Adjusted US FCI & $\begin{array}{l}-0.061 \\
(0.069)\end{array}$ & $\begin{array}{c}-0.062 \\
(0.066)\end{array}$ & $\begin{array}{c}0.020 \\
(0.012)\end{array}$ & $\begin{array}{c}-0.064 \\
(0.070)\end{array}$ & $\begin{array}{c}0.021 \\
(0.011)^{*}\end{array}$ \\
\hline $\log (\mathrm{US} \$$ US\$_FX_6) & $\begin{array}{c}-0.030 \\
(0.009)^{* * *}\end{array}$ & $\begin{array}{c}-0.022 \\
(0.010)^{* *}\end{array}$ & $\begin{array}{c}-0.026 \\
(0.012)^{* *}\end{array}$ & $\begin{array}{c}-0.026 \\
(0.010)^{* *}\end{array}$ & $\begin{array}{c}-0.030 \\
(0.011)^{* *}\end{array}$ \\
\hline Fixed ${ }^{*} \log ($ US\$_FX_6) & $\begin{array}{c}-0.027 \\
(0.014)^{*}\end{array}$ & $\begin{array}{c}-0.046 \\
(0.015)^{* *}\end{array}$ & $\begin{array}{c}-0.052 \\
(0.014)^{* * *}\end{array}$ & $\begin{array}{c}-0.035 \\
(0.015)^{* *}\end{array}$ & $\begin{array}{c}-0.037 \\
(0.013)^{* *}\end{array}$ \\
\hline Floating*log(US\$_FX_6) & $\begin{array}{l}-0.120 \\
(0.098)\end{array}$ & $\begin{array}{c}-0.124 \\
(0.084)\end{array}$ & $\begin{array}{c}-0.034 \\
(0.036)\end{array}$ & $\begin{array}{c}-0.137 \\
(0.092)\end{array}$ & $\begin{array}{l}-0.021 \\
(0.024)\end{array}$ \\
\hline Lagged GDP growth & $\begin{array}{c}0.309 \\
(0.052)^{* * *}\end{array}$ & $\begin{array}{c}0.302 \\
(0.052)^{* * *}\end{array}$ & $\begin{array}{c}0.190 \\
(0.033)^{* * *}\end{array}$ & $\begin{array}{c}0.305 \\
(0.050)^{* * *}\end{array}$ & $\begin{array}{c}0.181 \\
(0.034)^{* * *}\end{array}$ \\
\hline Lagged domestic private credit/GDP & $\begin{array}{c}-0.023 \\
(0.005)^{* * *}\end{array}$ & $\begin{array}{c}-0.023 \\
(0.006)^{* * *}\end{array}$ & $\begin{array}{c}-0.030 \\
(0.006)^{* * *}\end{array}$ & $\begin{array}{c}-0.022 \\
(0.005)^{* * *}\end{array}$ & $\begin{array}{c}-0.031 \\
(0.006)^{* * *}\end{array}$ \\
\hline Lagged CA/GDP & $\begin{array}{c}-0.142 \\
(0.031)^{* * *}\end{array}$ & $\begin{array}{c}-0.137 \\
(0.032)^{* * *}\end{array}$ & $\begin{array}{c}-0.127 \\
(0.027)^{* * *}\end{array}$ & $\begin{array}{c}-0.147 \\
(0.031)^{* * *}\end{array}$ & $\begin{array}{c}-0.125 \\
(0.028)^{* * *}\end{array}$ \\
\hline Domestic policy rate & & & $\begin{array}{c}-0.005 \\
(0.001)^{* * *}\end{array}$ & & $\begin{array}{c}-0.005 \\
(0.001)^{* * *}\end{array}$ \\
\hline Real US shadow federal funds rate & & $\begin{array}{c}-0.074 \\
(0.035)^{* *}\end{array}$ & $\begin{array}{l}-0.026 \\
(0.050)\end{array}$ & & \\
\hline Fixed*real shadow & & $\begin{array}{c}0.188 \\
(0.065)^{* *}\end{array}$ & $\begin{array}{c}0.224 \\
(0.053)^{* *}\end{array}$ & & \\
\hline Floating*real shadow & & $\begin{array}{c}0.126 \\
(0.372)\end{array}$ & $\begin{array}{c}0.412 \\
(0.202)^{*}\end{array}$ & & \\
\hline US term spread & & & & $\begin{array}{c}0.137 \\
(0.096)\end{array}$ & $\begin{array}{l}-0.020 \\
(0.123)\end{array}$ \\
\hline Fixed *US term spread & & & & $\begin{array}{c}-0.330 \\
(0.098)^{* * *}\end{array}$ & $\begin{array}{c}-0.348 \\
(0.097)^{* * *}\end{array}$ \\
\hline Floating*US term spread & & & & $\begin{array}{c}0.308 \\
(0.647) \\
\end{array}$ & $\begin{array}{c}-0.935 \\
(0.356)^{* *}\end{array}$ \\
\hline Observations & 1,330 & 1,330 & 1,185 & 1,330 & 1,185 \\
\hline Number of groups & 17 & 17 & 17 & 17 & 17 \\
\hline Adj. R-squared & 0.418 & 0.420 & 0.395 & 0.420 & 0.394 \\
\hline Country fixed effects & YES & YES & YES & YES & YES \\
\hline
\end{tabular}

Note: Driscoll-Kraay standard errors in parentheses; ${ }^{* *} p<0.01,{ }^{* *} p<0.05,{ }^{*} p<0.1$. Dependent variable is three-quarter moving average of quarterly real domestic private sector credit growth rate. Lagged variables are lagged 2 periods. All regressions include a dummy variable for banking crises, a dummy variable for the global financial crisis and a time trend. 
Table 7. Real credit growth: the role of the financial dependence on the US

\begin{tabular}{|c|c|c|c|c|c|}
\hline & $(1)$ & $(2)$ & (3) & $(4)$ & $(5)$ \\
\hline Lagged US\$DEBT/GDP & $\begin{array}{c}0.013 \\
(0.039)\end{array}$ & $\begin{array}{l}-0.065 \\
(0.042)\end{array}$ & $\begin{array}{c}-0.004 \\
(0.030)\end{array}$ & $\begin{array}{c}-0.018 \\
(0.038)\end{array}$ & $\begin{array}{l}-0.010 \\
(0.033)\end{array}$ \\
\hline $\log (\mathrm{VXO})$ & $\begin{array}{c}-0.023 \\
(0.007)^{* *}\end{array}$ & $\begin{array}{c}-0.021 \\
(0.007)^{* *}\end{array}$ & $\begin{array}{c}-0.016 \\
(0.005)^{* *}\end{array}$ & $\begin{array}{c}-0.029 \\
(0.008)^{* * *}\end{array}$ & $\begin{array}{c}-0.017 \\
(0.006)^{* *}\end{array}$ \\
\hline US\$DEBT* $\log (\mathrm{VXO})$ & $\begin{array}{c}-0.006 \\
(0.003)^{* *}\end{array}$ & $\begin{array}{c}-0.006 \\
(0.003)^{* *}\end{array}$ & $\begin{array}{c}-0.004 \\
(0.002)^{* *}\end{array}$ & $\begin{array}{c}-0.008 \\
(0.003)^{* *}\end{array}$ & $\begin{array}{c}-0.005 \\
(0.002)^{* *}\end{array}$ \\
\hline Adjusted US FCI & $\begin{array}{c}0.011 \\
(0.010)\end{array}$ & $\begin{array}{c}0.015 \\
(0.010)\end{array}$ & $\begin{array}{c}-0.007 \\
(0.005)\end{array}$ & $\begin{array}{c}0.014 \\
(0.010)\end{array}$ & $\begin{array}{l}-0.007 \\
(0.005)\end{array}$ \\
\hline US\$DEBT*adj. US FCI & $\begin{array}{c}0.004 \\
(0.004)\end{array}$ & $\begin{array}{c}0.005 \\
(0.004)\end{array}$ & $\begin{array}{c}-0.001 \\
(0.001)\end{array}$ & $\begin{array}{c}0.005 \\
(0.003)\end{array}$ & $\begin{array}{l}-0.002 \\
(0.002)\end{array}$ \\
\hline $\log (\mathrm{US} \$$ _FX_6) & $\begin{array}{c}-0.033 \\
(0.023)\end{array}$ & $\begin{array}{c}0.010 \\
(0.029)\end{array}$ & $\begin{array}{c}-0.031 \\
(0.016)^{*}\end{array}$ & $\begin{array}{c}-0.013 \\
(0.022)\end{array}$ & $\begin{array}{c}-0.026 \\
(0.015)^{*}\end{array}$ \\
\hline US\$DEBT*US\$_FX_6 & $\begin{array}{c}-0.001 \\
(0.008)\end{array}$ & $\begin{array}{c}0.017 \\
(0.009)\end{array}$ & $\begin{array}{c}0.003 \\
(0.006)\end{array}$ & $\begin{array}{c}0.007 \\
(0.008)\end{array}$ & $\begin{array}{c}0.004 \\
(0.007)\end{array}$ \\
\hline Lagged GDP growth & $\begin{array}{c}0.361 \\
(0.063)^{* * *}\end{array}$ & $\begin{array}{c}0.356 \\
(0.061)^{* * *}\end{array}$ & $\begin{array}{c}0.212 \\
(0.034)^{* * *}\end{array}$ & $\begin{array}{c}0.364 \\
(0.062)^{* * *}\end{array}$ & $\begin{array}{c}0.203 \\
(0.037)^{* * *}\end{array}$ \\
\hline Lagged domestic private credit/GDP & $\begin{array}{c}-0.020 \\
(0.007)^{* *}\end{array}$ & $\begin{array}{c}-0.020 \\
(0.007)^{* *}\end{array}$ & $\begin{array}{c}-0.027 \\
(0.006)^{* * *}\end{array}$ & $\begin{array}{c}-0.020 \\
(0.007)^{* *}\end{array}$ & $\begin{array}{c}-0.028 \\
(0.005)^{* * *}\end{array}$ \\
\hline Lagged CA/GDP & $\begin{array}{c}-0.116 \\
(0.035)^{* *}\end{array}$ & $\begin{array}{c}-0.123 \\
(0.035)^{* * *}\end{array}$ & $\begin{array}{c}-0.113 \\
(0.032)^{* * *}\end{array}$ & $\begin{array}{c}-0.121 \\
(0.036)^{* * *}\end{array}$ & $\begin{array}{c}-0.115 \\
(0.031)^{* * *}\end{array}$ \\
\hline Domestic policy rate & & & $\begin{array}{c}-0.005 \\
(0.001)^{* * *}\end{array}$ & & $\begin{array}{c}-0.005 \\
(0.001)^{* * *}\end{array}$ \\
\hline Real US shadow federal funds rate & & $\begin{array}{c}-0.420 \\
(0.151)^{* *}\end{array}$ & $\begin{array}{c}0.030 \\
(0.097)\end{array}$ & & \\
\hline US\$DEBT*real shadow & & $\begin{array}{c}-0.160 \\
(0.054)^{* *}\end{array}$ & $\begin{array}{l}-0.007 \\
(0.04)\end{array}$ & & \\
\hline US term spread & & & & $\begin{array}{c}0.781 \\
(0.314)^{* *}\end{array}$ & $\begin{array}{c}0.090 \\
(0.190)\end{array}$ \\
\hline US\$DEBT*US term spread & & & & $\begin{array}{c}0.289 \\
(0.099)^{* *}\end{array}$ & $\begin{array}{c}0.089 \\
(0.064)\end{array}$ \\
\hline Observations & 1,258 & 1,258 & 1,164 & 1,258 & 1,164 \\
\hline Number of groups & 17 & 17 & 17 & 17 & 17 \\
\hline Adj. R-squared & 0.392 & 0.397 & 0.361 & 0.396 & 0.363 \\
\hline Country fixed effects & YES & YES & YES & YES & YES \\
\hline
\end{tabular}

Note: Driscoll-Kraay standard errors in parentheses; ${ }^{* *} \mathrm{p}<0.01,{ }^{* *} \mathrm{p}<0.05,{ }^{*} \mathrm{p}<0.1$. Dependent variable is three-quarter moving average of quarterly real domestic private sector credit growth rate. Lagged variables are lagged 2 periods. All regressions include a dummy variable for banking crises, a dummy variable for the global financial crisis and a time trend. 
Table 8. Real credit growth: the role of the current account balance

\begin{tabular}{|c|c|c|c|c|c|}
\hline & $(1)$ & $(2)$ & (3) & $(4)$ & (5) \\
\hline $\log (\mathrm{VXO})$ & $\begin{array}{c}-0.008 \\
(0.003)^{* *}\end{array}$ & $\begin{array}{c}-0.007 \\
(0.002)^{* *}\end{array}$ & $\begin{array}{c}-0.006 \\
(0.002)^{* *}\end{array}$ & $\begin{array}{c}-0.008 \\
(0.003)^{* *}\end{array}$ & $\begin{array}{c}-0.005 \\
(0.002)^{* *}\end{array}$ \\
\hline $\mathrm{CA} / \mathrm{GDP}^{*} \log (\mathrm{VXO})$ & $\begin{array}{c}-0.024 \\
(0.062)\end{array}$ & $\begin{array}{c}-0.013 \\
(0.062)\end{array}$ & $\begin{array}{c}-0.014 \\
(0.046)\end{array}$ & $\begin{array}{l}-0.034 \\
(0.070)\end{array}$ & $\begin{array}{c}-0.025 \\
(0.055)\end{array}$ \\
\hline Adjusted US FCI & $\begin{array}{c}0.001 \\
(0.003)\end{array}$ & $\begin{array}{c}0.002 \\
(0.003)\end{array}$ & $\begin{array}{l}-0.002 \\
(0.003)\end{array}$ & $\begin{array}{c}0.002 \\
(0.003)\end{array}$ & $\begin{array}{c}-0.002 \\
(0.003)\end{array}$ \\
\hline CA/GDP*Adj. US FCI & $\begin{array}{c}0.063 \\
(0.076)\end{array}$ & $\begin{array}{c}0.064 \\
(0.077)\end{array}$ & $\begin{array}{c}0.076 \\
(0.051)\end{array}$ & $\begin{array}{c}0.059 \\
(0.075)\end{array}$ & $\begin{array}{c}0.062 \\
(0.056)\end{array}$ \\
\hline $\log (\mathrm{US} \$$ _FX_6) & $\begin{array}{c}-0.039 \\
(0.008)^{* * *}\end{array}$ & $\begin{array}{c}-0.034 \\
(0.010)^{* * *}\end{array}$ & $\begin{array}{c}-0.040 \\
(0.011)^{* * *}\end{array}$ & $\begin{array}{c}-0.036 \\
(0.009)^{* * *}\end{array}$ & $\begin{array}{c}-0.040 \\
(0.010)^{* * *}\end{array}$ \\
\hline CA/GDP*US\$_FX_6 & $\begin{array}{c}-0.221 \\
(0.259)\end{array}$ & $\begin{array}{c}-0.039 \\
(0.215)\end{array}$ & $\begin{array}{c}0.067 \\
(0.197)\end{array}$ & $\begin{array}{l}-0.179 \\
(0.261)\end{array}$ & $\begin{array}{l}-0.070 \\
(0.244)\end{array}$ \\
\hline Lagged GDP growth & $\begin{array}{c}0.363 \\
(0.063)^{* * *}\end{array}$ & $\begin{array}{c}0.362 \\
(0.059)^{* * *}\end{array}$ & $\begin{array}{c}0.239 \\
(0.031)^{* * *}\end{array}$ & $\begin{array}{c}0.366 \\
(0.060)^{* * *}\end{array}$ & $\begin{array}{c}0.222 \\
(0.035)^{* * *}\end{array}$ \\
\hline Lagged domestic private credit/GDP & $\begin{array}{c}-0.020 \\
(0.006)^{* * *}\end{array}$ & $\begin{array}{c}-0.020 \\
(0.006)^{* *}\end{array}$ & $\begin{array}{c}-0.026 \\
(0.005)^{* * *}\end{array}$ & $\begin{array}{c}-0.020 \\
(0.006)^{* * *}\end{array}$ & $\begin{array}{c}-0.027 \\
(0.005)^{* * *}\end{array}$ \\
\hline Lagged CA/GDP & $\begin{array}{c}0.924 \\
(1.119)\end{array}$ & $\begin{array}{c}0.079 \\
(0.908)\end{array}$ & $\begin{array}{c}-0.403 \\
(0.880)\end{array}$ & $\begin{array}{c}0.743 \\
(1.109)\end{array}$ & $\begin{array}{c}0.230 \\
(1.046)\end{array}$ \\
\hline Domestic policy rate & & & $\begin{array}{c}-0.005 \\
(0.001)^{* * *}\end{array}$ & & $\begin{array}{c}-0.005 \\
(0.002)^{* * *}\end{array}$ \\
\hline Real US shadow federal funds rate & & $\begin{array}{c}-0.045 \\
(0.036)\end{array}$ & $\begin{array}{c}0.029 \\
(0.042)\end{array}$ & & \\
\hline CA/GDP*real shadow & & $\begin{array}{c}-1.989 \\
(1.097)^{*}\end{array}$ & $\begin{array}{c}-2.032 \\
(1.066)^{*}\end{array}$ & & \\
\hline US term spread & & & & $\begin{array}{c}0.094 \\
(0.103)\end{array}$ & $\begin{array}{l}-0.107 \\
(0.107)\end{array}$ \\
\hline CA/GDP*US term spread & & & & $\begin{array}{c}1.816 \\
(1.996)\end{array}$ & $\begin{array}{c}1.851 \\
(1.988)\end{array}$ \\
\hline Observations & 1,330 & 1,330 & 1,185 & 1,330 & 1,185 \\
\hline Number of groups & 17 & 17 & 17 & 17 & 17 \\
\hline Adj. R-squared & 0.389 & 0.392 & 0.368 & 0.389 & 0.365 \\
\hline Country fixed effects & YES & YES & YES & YES & YES \\
\hline
\end{tabular}

Note: Driscoll-Kraay standard errors in parentheses; ${ }^{* * *} \mathrm{p}<0.01,{ }^{* *} \mathrm{p}<0.05,{ }^{*} \mathrm{p}<0.1$. Dependent variable is three-quarter moving average of quarterly real domestic private sector credit growth rate. Lagged variables are lagged 2 periods. All regressions include a dummy variable for banking crises, a dummy variable for the global financial crisis and a time trend. 
Table 9. Real credit growth: the role of the degree of financial integration

\begin{tabular}{|c|c|c|c|c|c|}
\hline & $(1)$ & $(2)$ & (3) & $(4)$ & (5) \\
\hline Financial integration & $\begin{array}{c}0.053 \\
(0.024)^{* *}\end{array}$ & $\begin{array}{c}0.050 \\
(0.021)^{* *}\end{array}$ & $\begin{array}{c}0.051 \\
(0.024)^{* *}\end{array}$ & $\begin{array}{c}0.045 \\
(0.025)^{*}\end{array}$ & $\begin{array}{c}0.034 \\
(0.026)^{*}\end{array}$ \\
\hline $\log (\mathrm{VXO})$ & $\begin{array}{c}-0.009 \\
(0.003)^{* *}\end{array}$ & $\begin{array}{c}-0.008 \\
(0.003)^{* *}\end{array}$ & $\begin{array}{c}-0.007 \\
(0.002)^{* *}\end{array}$ & $\begin{array}{c}-0.009 \\
(0.003)^{* *}\end{array}$ & $\begin{array}{c}-0.006 \\
(0.003)^{* *}\end{array}$ \\
\hline Financial integration* $\log (\mathrm{VXO})$ & $\begin{array}{c}0.000 \\
(0.002)\end{array}$ & $\begin{array}{c}0.000 \\
(0.002)\end{array}$ & $\begin{array}{c}0.001 \\
(0.002)\end{array}$ & $\begin{array}{c}-0.001 \\
(0.002)\end{array}$ & $\begin{array}{c}0.001 \\
(0.002)\end{array}$ \\
\hline Adjusted US FCI & $\begin{array}{c}0.001 \\
(0.003)\end{array}$ & $\begin{array}{c}0.002 \\
(0.003)\end{array}$ & $\begin{array}{c}-0.002 \\
(0.003)\end{array}$ & $\begin{array}{c}0.002 \\
(0.003)\end{array}$ & $\begin{array}{l}-0.002 \\
(0.003)\end{array}$ \\
\hline Financial integration*adj. US FCI & $\begin{array}{c}0.000 \\
(0.002)\end{array}$ & $\begin{array}{c}0.000 \\
(0.002)\end{array}$ & $\begin{array}{c}0.000 \\
(0.001)\end{array}$ & $\begin{array}{c}0.000 \\
(0.002)\end{array}$ & $\begin{array}{c}0.000 \\
(0.001)\end{array}$ \\
\hline $\log \left(U S \$ \_F X \_6\right)$ & $\begin{array}{c}-0.037 \\
(0.008)^{* * *}\end{array}$ & $\begin{array}{c}-0.033 \\
(0.010)^{* *}\end{array}$ & $\begin{array}{c}-0.038 \\
(0.011)^{* * *}\end{array}$ & $\begin{array}{c}-0.034 \\
(0.009)^{* * *}\end{array}$ & $\begin{array}{c}-0.038 \\
(0.011)^{* * *}\end{array}$ \\
\hline Financial integration*US\$_FX_6 & $\begin{array}{c}-0.012 \\
(0.005)^{* *}\end{array}$ & $\begin{array}{c}-0.011 \\
(0.005)^{* *}\end{array}$ & $\begin{array}{c}-0.013 \\
(0.006)^{* *}\end{array}$ & $\begin{array}{c}-0.010 \\
(0.006)^{* *}\end{array}$ & $\begin{array}{c}-0.009 \\
(0.006)^{*}\end{array}$ \\
\hline Lagged GDP growth & $\begin{array}{c}0.379 \\
(0.066)^{* * *}\end{array}$ & $\begin{array}{c}0.379 \\
(0.065)^{* * *}\end{array}$ & $\begin{array}{c}0.249 \\
(0.037)^{* * *}\end{array}$ & $\begin{array}{c}0.382 \\
(0.063)^{* * *}\end{array}$ & $\begin{array}{c}0.241 \\
(0.038)^{* * *}\end{array}$ \\
\hline Lagged domestic private credit/GDP & $\begin{array}{c}-0.019 \\
(0.005)^{* * *}\end{array}$ & $\begin{array}{c}-0.020 \\
(0.006)^{* * *}\end{array}$ & $\begin{array}{c}-0.026 \\
(0.005)^{* * *}\end{array}$ & $\begin{array}{c}-0.020 \\
(0.006)^{* * *}\end{array}$ & $\begin{array}{c}-0.027 \\
(0.005)^{* * *}\end{array}$ \\
\hline Lagged CA/GDP & $\begin{array}{c}-0.129 \\
(0.035)^{* * *}\end{array}$ & $\begin{array}{c}-0.133 \\
(0.035)^{* * *}\end{array}$ & $\begin{array}{c}-0.110 \\
(0.031)^{* * *}\end{array}$ & $\begin{array}{c}-0.128 \\
(0.035)^{* * *}\end{array}$ & $\begin{array}{c}-0.111 \\
(0.031)^{* * *}\end{array}$ \\
\hline Domestic policy rate & & & $\begin{array}{c}-0.006 \\
(0.002)^{* * *}\end{array}$ & & $\begin{array}{c}-0.006 \\
(0.002)^{* * *}\end{array}$ \\
\hline Real US shadow federal funds rate & & $\begin{array}{c}-0.039 \\
(0.044)\end{array}$ & $\begin{array}{c}0.031 \\
(0.043)\end{array}$ & & \\
\hline Financial integration*real shadow & & $\begin{array}{c}-0.010 \\
(0.031)\end{array}$ & $\begin{array}{c}0.029 \\
(0.025)\end{array}$ & & \\
\hline US term spread & & & & $\begin{array}{c}0.103 \\
(0.109)\end{array}$ & $\begin{array}{c}-0.087 \\
(0.110)\end{array}$ \\
\hline Financial integration*US term spread & & & & $\begin{array}{c}0.118 \\
(0.086)\end{array}$ & $\begin{array}{c}0.039 \\
(0.055)\end{array}$ \\
\hline Observations & 1,330 & 1,330 & 1,185 & 1,330 & 1,185 \\
\hline Number of groups & 17 & 17 & 17 & 17 & 17 \\
\hline Adj. R-squared & 0.389 & 0.389 & 0.375 & 0.392 & 0.376 \\
\hline Country fixed effects & YES & YES & YES & YES & YES \\
\hline
\end{tabular}

Note: Driscoll-Kraay standard errors in parentheses; ${ }^{* * *} \mathrm{p}<0.01,{ }^{* *} \mathrm{p}<0.05,{ }^{*} \mathrm{p}<0.1$. Dependent variable is three-quarter moving average of quarterly real domestic private sector credit growth rate. Lagged variables are lagged 2 periods. All regressions include a dummy variable for banking crises, a dummy variable for the global financial crisis and a time trend. 
Table 10. Real credit growth: the role of the degree of trade integration

\begin{tabular}{|c|c|c|c|c|c|}
\hline & (1) & $(2)$ & (3) & $(4)$ & (5) \\
\hline W_TRADE_INT & $\begin{array}{c}-0.092 \\
(0.031)^{* *}\end{array}$ & $\begin{array}{c}-0.131 \\
(0.025)^{* * *}\end{array}$ & $\begin{array}{c}-0.098 \\
(0.027)^{* * *}\end{array}$ & $\begin{array}{c}-0.109 \\
(0.020)^{* * *}\end{array}$ & $\begin{array}{c}-0.084 \\
(0.021)^{* * *}\end{array}$ \\
\hline $\log (\mathrm{VXO})$ & $\begin{array}{c}-0.008 \\
(0.003)^{* *}\end{array}$ & $\begin{array}{c}-0.007 \\
(0.002)^{* *}\end{array}$ & $\begin{array}{c}-0.005 \\
(0.002)^{* *}\end{array}$ & $\begin{array}{c}-0.008 \\
(0.003)^{* *}\end{array}$ & $\begin{array}{c}-0.004 \\
(0.002)^{*}\end{array}$ \\
\hline W_TRADE_INT* $\log (\mathrm{VXO})$ & $\begin{array}{c}0.003 \\
(0.001)^{* *}\end{array}$ & $\begin{array}{c}0.003 \\
(0.001)^{* *}\end{array}$ & $\begin{array}{c}0.003 \\
(0.001)^{* *}\end{array}$ & $\begin{array}{c}0.002 \\
(0.001)\end{array}$ & $\begin{array}{c}0.002 \\
(0.001)\end{array}$ \\
\hline Adjusted US FCI & $\begin{array}{c}0.002 \\
(0.003)\end{array}$ & $\begin{array}{c}0.005 \\
(0.003)\end{array}$ & $\begin{array}{c}0.000 \\
(0.003)\end{array}$ & $\begin{array}{c}0.003 \\
(0.003)\end{array}$ & $\begin{array}{c}-0.001 \\
(0.003)\end{array}$ \\
\hline W_TRADE_INT*adj. US FCI & $\begin{array}{c}0.005 \\
(0.002)^{* *}\end{array}$ & $\begin{array}{c}0.006 \\
(0.002)^{* * *}\end{array}$ & $\begin{array}{c}0.006 \\
(0.001)^{* *}\end{array}$ & $\begin{array}{c}0.006 \\
(0.002)^{* * *}\end{array}$ & $\begin{array}{c}0.006 \\
(0.001)^{* * *}\end{array}$ \\
\hline $\log (\mathrm{US} \$$ \$FX_6) & $\begin{array}{c}-0.040 \\
(0.008)^{* * *}\end{array}$ & $\begin{array}{c}-0.030 \\
(0.010)^{* *}\end{array}$ & $\begin{array}{c}-0.037 \\
(0.011)^{* * *}\end{array}$ & $\begin{array}{c}-0.037 \\
(0.009)^{* * *}\end{array}$ & $\begin{array}{c}-0.041 \\
(0.011)^{* * *}\end{array}$ \\
\hline W_TRADE_INT*US\$_FX_6 & $\begin{array}{c}0.013 \\
(0.007)^{*}\end{array}$ & $\begin{array}{c}0.021 \\
(0.006)^{* * *}\end{array}$ & $\begin{array}{c}0.015 \\
(0.006)^{* *}\end{array}$ & $\begin{array}{c}0.017 \\
(0.005)^{* * *}\end{array}$ & $\begin{array}{c}0.012 \\
(0.005)^{* *}\end{array}$ \\
\hline Lagged GDP growth & $\begin{array}{c}0.387 \\
(0.066)^{* * *}\end{array}$ & $\begin{array}{c}0.389 \\
(0.062)^{* * *}\end{array}$ & $\begin{array}{c}0.260 \\
(0.038)^{* * *}\end{array}$ & $\begin{array}{c}0.387 \\
(0.066)^{* * *}\end{array}$ & $\begin{array}{c}0.240 \\
(0.037)^{* * *}\end{array}$ \\
\hline Domestic private credit/GDP & $\begin{array}{c}-0.019 \\
(0.005)^{* * *}\end{array}$ & $\begin{array}{c}-0.021 \\
(0.006)^{* * *}\end{array}$ & $\begin{array}{c}-0.028 \\
(0.006)^{* * *}\end{array}$ & $\begin{array}{c}-0.020 \\
(0.005)^{* * *}\end{array}$ & $\begin{array}{c}-0.029 \\
(0.005)^{* * *}\end{array}$ \\
\hline Lagged CA/GDP & $\begin{array}{c}-0.105 \\
(0.033)^{* *}\end{array}$ & $\begin{array}{c}-0.110 \\
(0.032)^{* * *}\end{array}$ & $\begin{array}{c}-0.126 \\
(0.023)^{* * *}\end{array}$ & $\begin{array}{c}-0.104 \\
(0.032)^{* *}\end{array}$ & $\begin{array}{c}-0.124 \\
(0.021)^{* * *}\end{array}$ \\
\hline Domestic policy rate & & & $\begin{array}{c}-0.006 \\
(0.001)^{* * *}\end{array}$ & & $\begin{array}{c}-0.006 \\
(0.002)^{* * *}\end{array}$ \\
\hline Real US shadow federal funds rate & & $\begin{array}{c}-0.089 \\
(0.047)^{*}\end{array}$ & $\begin{array}{c}0.003 \\
(0.050)\end{array}$ & & \\
\hline W_TRADE_INT*real shadow & & $\begin{array}{c}-0.077 \\
(0.029)^{* *}\end{array}$ & $\begin{array}{c}-0.059 \\
(0.022)^{* *}\end{array}$ & & \\
\hline Term spread & & & & $\begin{array}{c}0.093 \\
(0.103)\end{array}$ & $\begin{array}{l}-0.115 \\
(0.116)\end{array}$ \\
\hline W_TRADE_INT*US term spread & & & & $\begin{array}{c}0.139 \\
(0.064)^{* *}\end{array}$ & $\begin{array}{c}0.150 \\
(0.055)^{* *}\end{array}$ \\
\hline Observations & 1,324 & 1,324 & 1,184 & 1,324 & 1,184 \\
\hline Number of groups & 17 & 17 & 17 & 17 & 17 \\
\hline Adj. R-squared & 0.423 & 0.429 & 0.406 & 0.427 & 0.414 \\
\hline Country fixed effects & YES & YES & YES & YES & YES \\
\hline
\end{tabular}

Note: Driscoll-Kraay standard errors in parentheses; ${ }^{* * *} \mathrm{p}<0.01,{ }^{* *} \mathrm{p}<0.05,{ }^{*} \mathrm{p}<0.1$. Dependent variable is three-quarter moving average of quarterly real domestic private sector credit growth rate. Lagged variables are lagged 2 periods. All regressions include a dummy variable for banking crises, a dummy variable for the global financial crisis and a time trend. 
Table 11. Robustness: Spillovers to Real stock returns in EMEs before and after the global financial crisis

Real stock market returns pre-crisis \begin{tabular}{cc}
\hline Variable & Estimated sign Significance \\
\hline \hline
\end{tabular} Direct impact of:

$\begin{array}{rcc}\text { VXO } & - & * * * \\ \Delta \mathrm{VXO} & - & * * * \\ \Delta \mathrm{US} \mathrm{FCI} & - & * * \\ \Delta \text { real US shadowrate } & - & * * \\ \text { US\$_FX_6 } & - & * \\ \text { Fixed FX } & + & \\ \text { Floating FX } & + & * \\ \text { US\$DEBT/GDP } & - & * * \\ \text { Financial integration } & + & * * \\ \text { USTRADEINT } & + & \\ \text { CA/GDP } & + & \end{array}$

Interaction terms with ER regime:

$\begin{array}{rcc}\text { Fixed*VXo } & - & * * * \\ \text { Floating*VXo } & - & * * \\ \text { Fixed } * \text { US FCI } & - & \\ \text { Flexible* } \Delta \text { US FCI } & + & * \\ \text { Fixed }{ }^{*} \text { US shadowrate } & - & * * \\ \text { Flexible* } \Delta \text { US shadowrate }^{*} & + & \end{array}$

Interaction terms with country fundamentals: US\$DEBT $/$ GDP* $\Delta$ real shadowrate $\quad+$ US\$DEBT/GDP* $\triangle$ US FCI

USTRADEINT* $\Delta$ real shadowrate USTRADEINT* ${ }^{*}$ US FCI

CA/GDP*VXO US\$DEBT/GDP*VXO
Real stock market returns post-crisis

\begin{tabular}{rrr}
\hline Variable & Estimated sign & Significance \\
\hline Direct impact of: & - & \\
VXO & - & $* * *$ \\
$\Delta V X O$ & - & $* * *$ \\
$\Delta$ US FCI & - & \\
Sreal US shadowrate & + & $* * *$ \\
US\$_FX_6 & - & \\
& & \\
Fixed FX & + & $*$ \\
Floating FX & - & \\
US\$DEBT/GDP & - & $* * *$ \\
Financial integration & + & \\
USTRADEINT & + & \\
CA/GDP & + &
\end{tabular}

Interaction terms with ER regime:

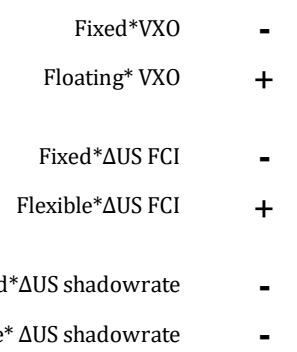

Interaction terms with country fundamentals: US\$DEBT $/ G D P * \Delta$ real shadowrate US\$DEBT /GDP* $\triangle$ US FCI USTRADEINT* ${ }^{*}$ real shadowrate USTRADEINT* $*$ US FCI CA/GDP*VXO US\$DEBT/GDP*VXO

Note: Driscoll-Kraay standard errors; ${ }^{* * *} \mathrm{p}<0.01,{ }^{* *} \mathrm{p}<0.05,{ }^{*} \mathrm{p}<0.1$. Dependent variable is the monthly real stock price growth rate. All regressions include a dummy variable for banking crisis. Delta stands for first difference of the indicated variable. Quarterly variables are lagged one quarter, monthly variables are lagged 1 month. The pre-crisis period runs from January 1995 to September 2008; the post crisis period runs from April 2009 to November 2018. $\Delta$ US FCI is orthogonal to VXO. Results are unchanged considering the VIX instead of the VXO. 
Table 12. Robustness: Spillovers to sovereign spreads in EMEs before and after the global financial crisis

$\Delta$ Sovereign spread pre-crisis

\begin{tabular}{rrrr}
\hline Variable & Estimated sign & Significan \\
\hline Direct impact of: & + & $* * *$ \\
$\Delta V \mathrm{VXO}$ & + & $* *$ \\
$\Delta \mathrm{US}$ FCI & + & \\
$\Delta$ US shadowrate & + & + & \\
US\$_FX_6 & + & $*$ \\
Fixed FX & + & $*$ \\
Floating FX & - & $*$ \\
US\$DEBT/GDP & + & $*$ \\
Financial integration & - & $*$ \\
USTRADEINT & - & $*$ \\
WTRADEINT & - & \\
CCA/GDP & - &
\end{tabular}

Interaction terms with ER regime:

\begin{tabular}{|c|c|c|}
\hline Fixed $* \Delta \mathrm{VXO}$ & + & $* *$ \\
\hline Floating* $\Delta \mathrm{VXO}$ & - & $* * *$ \\
\hline Fixed $* \Delta$ US FCI & - & \\
\hline Flexible* $\Delta$ US FCI & - & $* * *$ \\
\hline Fixed $* \Delta$ US shadowrate & + & $*$ \\
\hline Flexible* $\Delta$ US shadowrate & - & \\
\hline \multicolumn{3}{|l|}{ with country fundamentals: } \\
\hline $\mathrm{CA} / \mathrm{GDP} * \mathrm{VVXO}$ & - & $* * *$ \\
\hline US\$DEBT/GDP* $\triangle$ VXO & + & $* * *$ \\
\hline USTRADEINT/GDP*VXO & - & \\
\hline WTRADEINT/GDP*VXO & - & $* * *$ \\
\hline
\end{tabular}

$\Delta$ Sovereign spread post-crisis

\begin{tabular}{|c|c|c|c|}
\hline & Variable & Estimated sign & Significance \\
\hline \multicolumn{4}{|l|}{ Direct impact of: } \\
\hline & $\triangle \mathrm{VXO}$ & + & $* * *$ \\
\hline & $\Delta \mathrm{US} \mathrm{FCI}$ & + & $* * *$ \\
\hline & $\Delta$ US shadowrate & + & * \\
\hline & US\$_FX_6 & + & \\
\hline & Fixed FX & + & \\
\hline & Floating FX & + & \\
\hline & US\$DEBT/GDP & + & \\
\hline & Financial integration & - & \\
\hline & USTRADEINT & - & \\
\hline & WTRADEINT & - & \\
\hline & $\mathrm{CA} / \mathrm{GDP}$ & + & $*$ \\
\hline
\end{tabular}

Interaction terms with ER regime:

\begin{tabular}{|c|c|c|}
\hline Fixed $* \Delta V X O$ & + & $* * *$ \\
\hline Floating* $\Delta \mathrm{VXO}$ & + & \\
\hline Fixed $* \Delta$ US FCI & + & $* * *$ \\
\hline Flexible* $\Delta$ US FCI & - & \\
\hline Fixed ${ }^{*} \Delta$ US shad owrate & - & \\
\hline Flexible* $\Delta$ US shadowrate & - & * \\
\hline \multicolumn{3}{|l|}{ with country fundamentals: } \\
\hline CA/GDP*VXo & - & $* *$ \\
\hline US\$DEBT/GDP*VXO & + & $* * *$ \\
\hline USTRADEINT/GDP*VXO & - & \\
\hline WTRADEINT/GDP*VXO & - & $* * *$ \\
\hline
\end{tabular}

Note: Driscoll-Kraay standard errors; ${ }^{* * *} \mathrm{p}<0.01,{ }^{* *} \mathrm{p}<0.05, * \mathrm{p}<0.1$. Dependent variable is the first difference of the monthly average of spread on US dollar denominated sovereign bonds, in basis points. All regressions include a dummy variable for banking crisis. Quarterly variables are lagged one quarter, monthly variables are lagged 1 month. The precrisis period runs from January 1995 to September 2008; the post crisis period runs from April 2009 to November 2018. $\triangle$ US FCI is orthogonal to VXO. Results are unchanged considering the VIX instead of the VXO. 


\section{Appendix II. List of variables and countries}

\begin{tabular}{|c|c|c|}
\hline Variable & Description & Source \\
\hline Real stock returns & $\begin{array}{l}\text { Equity price index in national currency deflated by } \\
\text { consumer price }\end{array}$ & Refinitiv \\
\hline Sovereign Spread & JPM EMBI global, stripped spread & Refinitiv \\
\hline VXO & $\begin{array}{l}\text { Chicago Board Options Exchange Market Volatility } \\
\text { Index }\end{array}$ & Refinitiv \\
\hline Inflation rates & Consumer Prices, all items (\%YOY) & $\begin{array}{l}\text { IMF, International Financial } \\
\text { Statistics }\end{array}$ \\
\hline CA/GDP & Current account balance, quarterly, (\%GDP) & $\begin{array}{l}\text { IMF, International Financial } \\
\text { Statistics }\end{array}$ \\
\hline Credit/GDP & $\begin{array}{l}\text { Credit to Private non-financial sector, from all } \\
\text { sectors, local currency as \% of GDP }\end{array}$ & BIS \\
\hline Real credit growth & $\begin{array}{l}\text { Rate of growth of credit to private non financial } \\
\text { sector deflated by consumer price }\end{array}$ & $\begin{array}{l}\text { Autors' calculations based on BIS } \\
\text { and national statistics }\end{array}$ \\
\hline Real GDP growth & Real GDP growth rate $(\%, Y-o-Y)$ & OECD Quarterly national accounts \\
\hline Private credit/GDP & Credit to private non financial as $\%$ of GDP & BIS \\
\hline US T-Bill & US Treasury rate $10 \mathrm{Y}$ & Refinitiv \\
\hline Oil inflation & Rate of change of Brent Crude price (USD/barrel) & Refinitiv \\
\hline US\$_FX_6 & $\begin{array}{l}\text { Federal Reserve'sTrade-Weighted Exchange Value of } \\
\text { USD vs } 6 \text { Countries. }\end{array}$ & Federal Reserve of Chicago \\
\hline US adjusted FCI & $\begin{array}{l}\text { United States Adjusted National Financial Conditions } \\
\text { Index }\end{array}$ & Federal Reserve of Chicago \\
\hline Domestic policy rate & Monetary policy rate & Refinitiv \\
\hline US\$DEBT/GDP & $\begin{array}{l}\text { Credit (loans \& debt securities); cross border } \\
\text { denominated in USD as \% of GDP }\end{array}$ & BIS \\
\hline Financial Integration Index & IIP data: (Total assets+Total liabilities) $/ 2 * \mathrm{GDP}$ & $\begin{array}{l}\text { Authors' elaborations on Lane and } \\
\text { Milesi-Ferretti (2017) and IMF data }\end{array}$ \\
\hline $\begin{array}{l}\text { Trade Integration Index: World } \\
\left(\mathrm{W}_{-} \text {TRADE_INT) }\right.\end{array}$ & (Export to world+Imports from World ) $/ 2 * G D P$ & $\begin{array}{l}\text { Authors' elaboration based on IMF, } \\
\text { DOTS and IFS databases }\end{array}$ \\
\hline $\begin{array}{l}\text { Trade Integration Index: USA } \\
\text { (US_TRADE_INT) }\end{array}$ & (Export to USA+Imports from USA) $/ 2 * \mathrm{GDP}$ & $\begin{array}{l}\text { Authors' elaboration based on IMF, } \\
\text { DOTS and IFS databases }\end{array}$ \\
\hline bank crisis dummy & dummy for systemic bank crisis & $\begin{array}{l}\text { Data file to accompany paper } \\
\text { "Systemic Banking Crises } \\
\text { Revisited", by Luc Laeven and }\end{array}$ \\
\hline Portfolio liability flows/GDP & $\begin{array}{l}\text { 3-quarter moving average of portfolio liability } \\
\text { inflows as \% of GDP }\end{array}$ & Authors' elaborations on IMF data \\
\hline US Federal Funds rate or shadow rate & $\begin{array}{l}\text { WU-XIA Federal Funds shadow rate until 11/2015; } \\
\text { Federal funds rate afterwards }\end{array}$ & Refinitiv \\
\hline Foreign exchange reserves & $\begin{array}{l}\text { International foreign exchange reserves (excluding } \\
\text { gold) as \% GDP }\end{array}$ & $\begin{array}{l}\text { IMF, International Financial } \\
\text { Statistics }\end{array}$ \\
\hline GOV DEBT/GDP & $\begin{array}{l}\text { Credit to General Government, Provided by All Sectors } \\
\text { as } \% \text { GDP }\end{array}$ & BIS \\
\hline NEER & Nominal effective exchange rate & Refinitiv \\
\hline US term spread & $\begin{array}{l}\text { 10-Year Treasury Constant Maturity Minus 3-Months } \\
\text { Treasury Constant Maturity }\end{array}$ & Federal Reserve Bank of St. Louis \\
\hline
\end{tabular}


List of emerging economies in the sample

\begin{tabular}{lll}
\hline Brazil & India & Poland \\
Chile & Indonesia & Russia \\
China & South Korea & South Africa \\
Colombia & Malaysia & Thailand \\
Czech Republic & Mexico & Turkey \\
Hungary & Philippines & \\
\hline
\end{tabular}

